\title{
Sürdürülebilir Turizm Planlaması İçin Yöre Halkı ve Yerli Turistlerin Davranış ve Beklentilerini Anlamaya Yönelik Bir Araştırma; Akçakoca Örneği ${ }^{*}$
}

\section{A Research on The Attitude and Expectations of Tourists and Citizens of The Area for Sustainable Tourism Planning; Case of Akçakoca}

\author{
Aslı ALTANLAR ${ }^{1}$, Güniz AKINCI KESİM ${ }^{2}$ \\ ${ }^{l}$ Yıldız Teknik Üniversitesi Mimarlık Fakültesi Şehir ve Bölge Planlama Bölümü, İstanbul \\ ${ }^{2}$ Düzce Üniversitesi Orman Fakültesi Peyzaj Mimarlı̆̆ı Bölümü, Düzce
}

\begin{abstract}
Özet: Doğal kaynakların plansızca tüketildiği günümüz dünyasında, her alanda olduğu gibi turizmde de sürdürülebilirlik kavramı giderek önem kazanmaktadır. Turizmde sürdürülebilirliği sağlamak amacıyla, çevre sorunlarına daha duyarlı olan turizm planlarını geliştirmek gerekmektedir. Yerel halk ve çevreye olan saygının geliştirilmesiyle hem sürdürülebilir bir turizmin gelişmesi sağlanabilmekte hem de daha seçici olan yeni turist profilleri için kentsel cazibe arttırılabilmektedir. Dolayıslyla turizmde sürdürülebilirliği sağlamak için yönetici ve planclların kentlerde turizmin sadece sayısal talep boyutunu değil, doğal ve kültürel çevreye duyarl, yerel halk ve turistlerin davranış ve beklentilerini de anlamaya çalışan bir anlayıs ortaya koyması gerekmektedir. Bu amaçla bu çalı̧̧mada, Akçakoca ilçesindeki turizm sisteminin kalitesi, ürünleri, hizmetleri, turizm faaliyetlerine olan eğilim, turizm amaçlı kullanılan alanlar, alanlardaki kısıtlayıcı nedenler, kullanım yoğunluğu ve turistik alanlardaki memnuniyetleri belirlemek için yarıstandart anket formları hazırlanmış ve 500 katılımcıya uygulanmıştır. Anket verilerinin çözümlenmesinde bilgisayar destekli istatistik programı kullanılmış ve Faktör Analizinin yanı sıra Tek Faktörlü Varyans Analizi ve T testi yapılmıştır. Elde edilen veriler, bulgular bölümünde çizelgelerle belirtilmiştir. Sonuç olarak, hem plancı ve hem de kullanıcı baklş açısıyla ilçenin turizm faaliyetlerinde karşılaşılan sorunlar tartışılmış, turizm potansiyeli olan alanlarda koruma-kullanma dengesinin sağlandığı alternatif bir turizm gelişmesi için bazı çözüm önerileri getirilmiştir. Anahtar Kelimeler: Sürdürülebilir turizm, Planlama, Kullanıcı davranışları, Akçakoca.
\end{abstract}

\begin{abstract}
As a result of unplanned consumption of natural resourses, sustainability is getting more and more important also in tourism as well as in many other fields in todays World. To ensure sustainability in tourism, environmentally sensitive tourism planning must be developed. Sustainable toursim can be obtained by respecting local people and environment, so that new selective tourist profiles can be attracted to the city. Therefore, in order to attain sustainability in tourism, the urban planners and governers should not consider it only as a quantitative demand. Attitudes and ezpectations of local people and tourists must be taken into account while the plans must be sensitive to both natural and culturel environment. In this context, semi standart survey forms have been applied to 500 people to analyze the quality of the tourism system, its products, services, tendency towards tourism events, places used for touristic aims, restrictions offin those areas, density of usage and the pleasement of the clients in Akçakoca. In the analysis of the survey computer based statistics programs were used and, Factor Analysis besides Single Factor Variation analysis and T test were applied.In conclusion, the problems faced in tourism events in the Akçakoca district were discussed, from both the planner and the user and some solutions were proposed to develop an alternative tourism in which usage - protection balance ensured in the potantial tourism areas

Key words: Sustainable tourism, Planning, User behavior, Akçakoca.
\end{abstract}

\footnotetext{
* Bu çalışma yüksek lisans tezinden yararlanılarak hazırlanmıştır.
} 


\section{A.Altanlar ve G.Akıncı Kesim}

\section{Giriş}

Tarih boyunca değişen ekonomik koşullar, gelişen teknoloji ve bunların etkilediği sosyal ve kültürel yapı kent mekânını da etkilemiştir. Yöneticiler, plancılar ve uzmanlar sanayisizleşme süreci içinde ekonomileri derinden sarsılan kentlerin küresel haritada yerlerini belirginleştirerek adlarını markalaştırmak ve diğer kentler üzerinde, rekabete dayalı bir imgesel üstünlük yaratabilmek için yeni kentsel politikalar ve stratejiler geliştirmektedirler. Bu stratejiler içerisinde turizm, kentsel imaj ve ekonomik gelişmenin sağlanmasında önemli bir rol üstlenmiştir. Turizmin geliştirilmesi, turistler açısından kentlerin çekiciliğinin arttırılması, kentsel imajın belirlenmesi, kentin kimliğinin güçlendirilmesi, yerel ekonomik kalkınmanın desteklenmesi, istihdam yaratılması, yurttaşların yaşam kalitesinin arttırılması ve kentsel ekosistemin sürdürülebilirliğinin sağlanması gibi geniş bir çerçeveden ele alınmaktadır (Grodach ve Loukaitou-Sideris, 2007; Keating ve Frantz, 2004; Sınmaz ve Ark., 2010).

Dünya turizm sektörü, uzun y1llar kitlesel turizm üzerine kurulmuştur. Yerel yönetimler turizmi geliştirirken, kente miras kalan kentin coğrafyası, topoğrafyası, tarihi, kültür ve geleneklerini turistlere pazarlamakta ancak varolanı korumak, ona şekil vermek ve biçimlendirmek konusunda yetersiz kalmaktadırlar. Bu yetersizlik doğal ve kültürel kaynakların plansızca tüketilmesine ve fiziksel çevre üzerinde onarımı güç tahribatların meydana gelmesine neden olmaktadır. Değişen turist profili ve kitlesel turizmin fiziksel ve sosyal çevreye verdiği olumsuz koşullar görülmeye başlandığında ise, turizm sektöründe her zaman varolan risk faktörü en aza indirilerek, turizm sektörünün sürdürülebilirliğini sağlamak amaciyla kitlesel turizme alternatif oluşturabilecek yeni turizm türlerinin geliştirilmesi gündeme gelmiştir.

Turizmde sürdürülebilirliği sağlamak için kentlerde yönetici ve plancıların, turizmin sadece sayısal talep boyutunu değil, doğal ve kültürel çevreye duyarlı, yerel halk ve turistlerin davranış ve beklentilerini de anlamaya çalışan bir anlayış ortaya koyması gerekmektedir. Bu amaçla, yönetici ve plancılar öncelikle ortaya çıkan bu yeni zihniyet değişikliklerini değerlendirmeli, doğal ve kültürel çevrenin potansiyelini belirlemeli, turistik aktiviteler ile aktiviteler arası ilişkileri ortaya koymalı ve yerel halkın ve turistlerin kentsel çevredeki çeşitli olanakları nasıl kullandıklarını anlayarak koruma ve kullanma dengesinin sağlandığı sürdürülebilir bir turizm anlayışı ortaya koymalıdır (Enlil ve Ark., 2011; Kerimoğlu ve Çıracı, 2006). Ancak, bu şekilde yapılan planlar ile kentlerin turistler açısından çekiciliği arttırılırken, kentin kendine has kültürünün ve doğal, tarihi ve kültürel miras alanlarının zedelenmesinin önüne geçilebilir. Aksi takdirde ticari kaygıların ön plana çıktığı bir turizm planlamasında, doğal, tarihi ve kültürel mirasın korunamamasına ek olarak, sosyal bozulma, toplum yapısında değiş̧iklik, ziyaretçiler ve o bölgede yaşayanlar arasında sorunların ortaya çıkacağı da unutulmamalıdır (Türkün, 2007).

Aslında son 10-15 yıldır yapılan araştırmalar sadece turizm sektörü açısından değil, turistler açısından da eğilimlerin değiştiğini ve kitlesel turizme olan ilginin azalarak özgün ve tekil olana duyulan ilginin arttığını, alternatif turizm türlerine yönelişin giderek güçlendiğini, doğal alanlar, tarihi ve kültürel miras ile çeşitli sanatsal ve kültürel aktivitelerin artık turistlerin en önemli seyahat nedenleri arasında ilk sıralarda yer aldığını göstermektedir (Enlil ve Ark., 2011; Özer, 2010; Maitland, 2007; Erdoğan, 2003). Anlaşıldığ1 üzere yapılan araştırmalar, geleceğin turistinin turistik ürün satın alma davranışlarında giderek çok daha seçici olacağı yönünde yoğunlaşmaktadır. Dolayısıyla ülkemizin doğal, tarihi ve kültürel kaynaklarının potansiyelinin devam ettirilmesi ve dünya turizminde mevcut olan pazarının korunabilmesi amacıyla sürdürülebilir bir yaklaşımla turizm anlayışının benimsenmesinin gerekliliği açıkça görülebilmektedir. Bu noktada değişen turizm anlayışlarına ayak uydurabilmek, doğal ve kültürel kaynakların sürdürülebilirliğini sağlamak ve turizm için potansiyel arz eden alanları belirleyebilmek için peyzaj plancılarına da önemli görev ve sorumluluklar düşmektedir. 
Bu çalışmada, bu veriler 1şığında araştırma alanı olarak 1947 yılında daha Ege ve Akdeniz kıyıları henüz turizme açılmamışken, turizm potansiyeli keşfedilmiş Düzce ilinin Karadeniz'e tek kıyısı olan Akçakoca ilçesi seçilmiştir. Araştırma alanının Akçakoca olarak seçilmesinde; Akçakoca'nın yanlış arazi kullanımları ve turizm politikaları sonucunda hızla doğal ve kültürel kaynaklarını kaybediyor olması önemli bir etken oluşmuştur. Akçakoca'da turizmi dört mevsime yayarak koruma kullanma dengesinin göz önünde bulundurulduğu sürdürülebilir bir turizm anlayışını geliştirebilmek, yöre halkı ve turistlerin davranış ve beklentilerini anlayabilmek amacıyla yöre halkı ve yerli turistler pek çok değişken çerçevesinde incelenmiş ve değerlendirilmiştir.

\section{Materyal ve Yöntem}

Alanın sosyal koşullarını ortaya koyabilmek için veri toplarken yöre halkı ve yerli turistlerin sosyo-ekonomik yapılarını ve turizm amaçlı faaliyetlerdeki genel eğilimlerini, alışkanlıklarını, kullanılan alanları, turist yoğunluğunu ve turistlerin seyahat özelliklerini gözlemleyebilmek ve turizmde yanlış kaynak kullanımı ve plansız gelişmeden doğan çeşitli sorunları yerinde tespit etmek amacıyla anket çalışmasından yararlanılmıştır. Soruların hazırlanmasında; Dawson, Newman and Watson (1997), Newman and Dawson (1998), Parasurman and etc. (1988), Mackay and Cropton (1990) çalışmalarından yararlanılmış ve konuyla ilgili elde edilen bilgiler doğrultusunda uzman görüşlerine de başvurulmuştur.

Yarıstandart olan ve beş bölümden oluşan anket, Akçakoca ilçesinde yaşayan yöre halkı ve yöreye gelen yerli turistlere uygulanmıştır. Bu amaçla 22 adet soru sorulmuştur. Sorulara verilebilecek alternatif seçenekler daha önceden hazırlanıp, ankete katılan kişilerden araştırmanın amacına göre bir veya daha fazla seçeneği işaretlemesi istenmiştir.

Anketin birinci bölümünde, yöre halkı ve yerli turistlerin demografik özelliklerini (cinsiyet, yaş, medeni durum, meslek, eğitim durumu, gelir seviyelerini, ikamet yerleri) belirlemek amaciyla 7 adet, ikinci bölümde, yerli turistlerin seyahat özelliklerini ortaya koymak amaciyla, yöreye geldikleri ili, yöreye kaçıncı kez geldiğini, yöreyi ziyaret etme sıklığını, konakladığı gün sayısını, konaklama yaptığ 1 yeri, yöreye hangi mevsimde gelmeyi tercih ettiğini ve yöreye kiminle geldiğini belirlemek amacıyla 7 adet, üçüncü bölümünde katılımcıların Akçakoca'nın beğendikleri özelliklerini, Akçakoca için uygun buldukları turizm türlerini, Akçakoca'da turizm etkinliklerini gerçekleştirmek için tercih ettikleri alanları, bu alanlardaki rekreasyonel aktivite taleplerini, bu alanlardan faydalanma sıklığını, alanlara ulaşım şeklini ve bu alanlara gidememe nedenlerini belirlemek amaciyla 8 adet soru sorulmuştur. Anketin dördüncü bölümünde, yöre halkının ve yerli turistlerin Akçakoca'daki turizm alanları açısından memnuniyetlerini ve bunu etkileyen kriterleri belirlemek içinse Parasurman ve ark. (1988)'nın müşteri memnuniyetini belirlemede kullandığ SERVQUAL ile, Mackay and Cropton (1990)'un rekreasyon alanlardaki kullanıcı memnuniyetini belirlemede kullandığ 1 REQUAL yönteminden yararlanılmıştır. Bu bölümde, yöre halkı ve yerli turistlerin memnuniyetini arttıran etmenleri belirlemek için 20 yargı, memnuniyetini azaltan etmenleri belirlemek için ise 25 yargı oluşturulmuş ve söz konusu bu yargılar 5'li Likert tipi ölçek ile derecelendirilmiştir.

Akçakoca'daki turizm hareketleri incelendiğinde, genelde ilçeye olan turistik hareketlerin yaz aylarında yoğunlaştığı gözlenmektedir. Bu doğrultuda araştırmanın evrenini Haziran, Temmuz ve Ağustos aylarında Akçakoca yöresini ziyaret eden tüm turistler ve yöre halkı oluşturmaktadır. Araştırmada anket uygulaması, evreni oluşturan bireylerin tamamı yerine, zaman ve maliyet sınırlılığı gibi nedenlerden dolayı, evreni temsil edebilecek düzeyde örneklem üzerinde gerçekleştirilmiştir. Araştırmalarda, evren hacminin büyüklüğü $(\mathrm{N}>10.000$ veya $\mathrm{N}<10.000)$, değişkenlerin türü (nitel veya nicel) ve güven düzeyinin (1- $\alpha$ ) göz önünde bulundurulup bulundurulmayacağ 1 gibi belirleyiciler dikkate alınarak, evreni temsil edebilecek örneklem hacminin belirlenmesinde kullanılan formülden yararlanılmıştır (Ural ve Kılıç, 2005). 


$$
n=\frac{\sigma^{2} \cdot z_{\alpha}^{2}}{H^{2}} \begin{aligned}
& \text { n: Örneklem büyüklüğ̈̈ (örnekleme dahil edilecek birey sayısı) } \\
& \begin{array}{l}
\text { H: Standart sapma değeri hata değeri (evren ve örneklem ortalaması arasında izin } \\
\text { verilebilecek maksimum fark) } \\
\text { z: Belirli bir } \alpha \text { anlamlılı düzeyine (yanılma olasılık değerine) karşılık } \\
\text { gelen teorik değer }
\end{array}
\end{aligned}
$$

$$
\begin{aligned}
& \alpha=0,01 \text { için } \sigma=1,1 ; \mathrm{z}_{, 01}=2,58 ; \mathrm{H}= \pm 0,15 \Rightarrow n=\frac{1,1^{2} \cdot 2,58^{2}}{0,15^{2}}=358 \\
& \alpha=0,05 \text { için } \sigma=1,1 ; \mathrm{z}_{0,05}=1,96 ; \mathrm{H}= \pm 0,15 \Rightarrow n=\frac{1,1^{2} \cdot 1,96^{2}}{0,15^{2}}=207
\end{aligned}
$$

$\mathrm{Bu}$ sonuçlar doğrultusunda, örneklem evreni değerlendirmeye alınmayacak derecede eksik veriler içeren anketlerin de olabileceği dikkate alınarak 250 yöre halkı, 250 yerli turist olmak üzere 500 kişi olarak belirlenmiş ve anket 2007 yılında uygulanmıştır. Örneklem grubunu oluşturan bireyler kolay örnekleme yöntemi ile seçilmiştir. Örneklem grubu üzerinde uygulanan anketlerin geri dönüşümünden sonra, yapılan kontrollerde eksik ya da hatalı kodlamalar tespit edilen bazı anket formları değerlendirme dışı bırakılmış ve toplam 435 anket formu değerlendirmeye alınmıştır.

Elde edilen veriler çözümlenirken, frekans ve yüzde dağılımlarını ifade edebilmek için "Frekans Analizi", memnuniyet düzeylerini belirleyebilmek için "Faktör Analizi", elde edilen faktör gruplarının güvenirliliğini ortaya koymak için "Cronbach's Alpha Analizi” yapılmıştır. \% 70 güvenirlik oranının altına düşen faktör grupları değerlendirmeye alınmamıştır. Son bölümde, Faktör Analizi ile elde edilen faktör grupları ile demografik yapı ve seyahat özelliklerine ilişkin bazı değişkenler arasında anlamlı bir farklılık bulunup bulunmadığına dair veri elde etmek amacıyla Bağımsız Örneklemler için TekFaktörlü Varyans Analizi (One-Way ANOVA) ve Bağımsız Örneklemler için T Testi (IndependentSamples $\mathrm{T}$ Test) analizleri yapılmış ve elde edilen istatistiki veriler çizelgeler halinde sunularak açıklanmıştır.

\section{Bulgular}

\subsection{Yöre Halk1 ve Yerli Turistlerin Demografik Özellikleri}

Ankete katılan yöre halkı ve yerli turistlerin (katılımcıların) \% 49,7'si bay, \% 49,7'si ise bayandır. Katılımciların \% 8,7'si 19 ve alt1, \% 50,8'i 20-29, \%18,2'si 30-39, \% 11,5'i 40-49, \% 7,6's1 50-59, \% 2,8'inin ise 60 yaş ve üstü olduğu, \% 6,6'sının ilköğretim, \% 31,7'sinin lise, \% 14,3'ünün ön lisans, \% 38,9'unun lisans, \%7,6'sının ise lisansüstü eğitim seviyesine sahip olduğu tespit edilmiştir. Katılımcıların \% 40,9'unun evli, \% 58,4'ünün bekar olup; \% 27,4'ünün 500 YTL'den az, \% 31,3'ünün 500-1000 YTL aras1, \% 15,9'unun 1001-1500 YTL aras1, \% 7,8'inin 1501-2000 YTL aras1, \% 7,4'ünün ise 2001 ve üstü bir aylık gelire sahip olduğu belirlenmektedir (Çizelge 1).

Katılımcıların \% 14,3'ü memur, \% 9'u işçi, \% 1,1'i çiftçi, \% 32,4'ü öğrenci, \% 10,1'i ev hanımı, \%7,4'ü emekli, \% 10,3 serbest meslek, \% 15,2'si diğer seçeneğini işaretleyerek; sözleşmeli öğretmen, özel sektörde; avukat, mimar-mühendis, teknik eleman olduklarını belirtmişlerdir. Ayrıca katılımcıların \% 43,9'u Akçakoca'da ikamet ederken, \% 55,6' sının ise ikamet etmediği belirlenmiştir (Çizelge 1). 
Çizelge 1.Yöre halkı ve yerli turistlerin demografik özellikleri.

\begin{tabular}{|c|c|c|c|c|c|c|c|}
\hline \multicolumn{2}{|c|}{ Demografik Özellikler } & $\mathrm{F}$ & $\%$ & \multicolumn{2}{|c|}{ Demografik Özellikler } & $\mathrm{F}$ & $\%$ \\
\hline \multirow{3}{*}{ Cinsiyet } & Bay & 216 & 49,7 & \multirow{9}{*}{ Meslek } & Memur & 62 & 14,3 \\
\hline & Bayan & 216 & 49,7 & & İşçi & 39 & 9,0 \\
\hline & Boş & 3 & 0,7 & & Çiftçi & 5 & 1,1 \\
\hline \multirow{7}{*}{ Yaş Grubu } & 19 ve alt1 & 38 & 8,7 & & Öğrenci & 141 & 32,4 \\
\hline & $20-29$ & 221 & 50,8 & & Emekli & 32 & 7,4 \\
\hline & $30-39$ & 79 & 18,2 & & Ev hanımı & 44 & 10,1 \\
\hline & $40-49$ & 50 & 11,5 & & Serbest Meslek & 45 & 10,3 \\
\hline & $50-59$ & 33 & 7,6 & & Diğer & 66 & 15,2 \\
\hline & 60 ve üzeri & 12 & 2,8 & & Boş & 1 & 0,2 \\
\hline & Boş & 2 & 0,5 & \multirow{6}{*}{$\begin{array}{l}\text { Aylik } \\
\text { Gelir }\end{array}$} & 500den az & 119 & 27,4 \\
\hline \multirow{6}{*}{ Eğitim Durumu } & Ilköğretim & 29 & 6,6 & & $500-1000$ & 136 & 31,3 \\
\hline & Lise & 138 & 31,7 & & $1001-1500$ & 69 & 15,9 \\
\hline & Ön lisans & 62 & 14,3 & & $1501-2000$ & 34 & 7,8 \\
\hline & Lisans & 169 & 38,9 & & 2001 ve üstü & 32 & 7,4 \\
\hline & $\begin{array}{l}\text { Yüksek } \\
\text { lisans }\end{array}$ & 33 & 7,6 & & Boş & 45 & 10,3 \\
\hline & Boş & 4 & 0,9 & \multirow{4}{*}{$\begin{array}{l}\text { İkametgah } \\
\text { Durumu }\end{array}$} & Akçakoca'da yaşıyorum & 191 & 43,9 \\
\hline \multirow{3}{*}{ Medeni Durum } & Evli & 178 & 40,9 & & $\begin{array}{l}\text { Akçakoca'da } \\
\text { yaşamıyorum }\end{array}$ & 242 & 55,6 \\
\hline & Bekar & 254 & 58,4 & & Boş & 2 & 0,5 \\
\hline & Boş & 3 & 0,3 & & Toplam & 435 & 100,0 \\
\hline
\end{tabular}

\subsection{Yerli Turistlerin Seyahat Özellikleri}

Yerli turistlerin seyahat özelliklerine ilişkin frekans ve yüzde dağılımları Çizelge 2'de verilmiştir. Ankete yanıt veren turistlerin, \% 23,6'sı konaklamıyorum seçeneğini işaretlerken, \% 28, ' ${ }^{\prime} i$ konaklama yeri olarak yazlıkları, \% 3,7'si pansiyonları, \% 4'ü kampingleri, \% 7,4'ü otelleri tercih ettiklerini, \% 31'i ise diğer seçeneğini işaretleyerek; aile, akraba, arkadaş, köy ve öğrenci evleri ile akraba veya arkadaşlarının yazlıklarında, konaklamayı tercih ettiklerini belirtmişlerdir. Turistlerin Akçakoca'yı ziyaret etme sayılarına ilişkin verdikleri yanıtlar incelendiğinde; \% 7,4'ünün ilk kez, \% 3,3’ünün ikinci kez, \% 3,3'ünün de üçüncü kez, \% 80,2'sinin ise dört ve daha fazla sayıda yöreyi ziyaret ettikleri anlaşılmaktadır (Çizelge 2).

Yerli turistlerin Akçakoca'ya geliş sıklıklarına ilişkin verdikleri yanıtlar incelendiğinde; \% 7,9'unun haftada bir, \% 11,6'sının 15 günde bir, \% 9,1'inin ayda bir, \% 13,2'sinin üç ayda bir; \% 10,7 'sinin y1lda bir, \% 22,7'sinin ise diğer seçeneğini işaretleyerek; genellikle yaz sezonunda sürekli ya da 5-6 kez, tatillerde ve okul dönemi boyunca hafta içi, Akçakoca'ya geldikleri belirlenebilmektedir. Yerli turistlerin yöreye geldikleri illere ilişkin verdikleri yanıtlar incelendiğinde ise; ilk üç sırada \% 26,9 ile Düzce merkez ve ilçeleri, \% 9,1 ile Ankara, ve \% 7,9 ile Bolu'nun yer aldığ 1 görülmektedir. Yerli turistlerin \% 30,2'inin günübirlik olarak Akçakoca'ya gelmeyi tercih ettiği tespit edilirken, \% 16,9'u 1-3 gün, \% 4,5'i 4-6 gün, \% 9,1'i bir hafta, \% 7'si 15 gün, \% 28,1'i 1 ay ve daha fazla zaman dilimlerinde Akçakoca'da kaldıklarını bildirmişlerdir. Yerli turistlerin yöreye birlikte gelinen kişi ya da kişiler seçeneğine; \% 53,7'sinin ailem, \%33,1'ninde arkadaşlarımla, \%14'nünde yalnız cevabını verdikleri, yöreyi ziyaret etmeyi tercih ettikleri mevsimin ise; \% 92,6'lik bir oranla yaz mevsimi olduğu tespit edilirken, \% 24'lük oranla kış, \% 2,8'lik oranla ilkbahar ve \% 10,3'lük oranla sonbahar mevsimlerini de tercih ettikleri anlaşılmaktadır. Kış aylarındaki talep artışında yöreye eğitim amaçlı gelen öğrencilerin etkisinin olduğu düşünülmektedir. Turistlerin daha çok bireysel turizm yaptıkları tespit edilirken, konaklama yeri olarak en çok yazlıkları tercih ettiği, otel, pansiyon ve kampinglerin ise daha az tercih edildiği görülmektedir. Bunun nedeni olarak, otel, pansiyon ve kampinglerin uluslararası standartlarda olmaması ve buna rağmen konaklama ücretlerinin pahalı olmasının etkili olduğu düşünülmektedir. 


\section{A.Altanlar ve G.Akıncı Kesim}

Çizelge 2. Turistlerin seyahat özellikleri.

\begin{tabular}{|c|c|c|c|c|c|c|c|}
\hline \multirow{8}{*}{$\begin{array}{l}\text { Yöreye geliş } \\
\text { s1klığ1 }\end{array}$} & & $\mathrm{F}$ & $\%$ & \multirow{8}{*}{$\begin{array}{l}\text { Yörede } \\
\text { Konaklama } \\
\text { Süresi }\end{array}$} & & $\mathrm{F}$ & $\%$ \\
\hline & Haftada bir & 19 & 7,9 & & Günübirlik & 73 & 30,2 \\
\hline & 15 günde bir & 28 & 11,6 & & $1-3$ gün & 41 & 16,9 \\
\hline & Ayda bir & 22 & 9,1 & & $4-6$ gün & 11 & 4,5 \\
\hline & Üç ayda bir & 32 & 13,2 & & 1 hafta & 22 & 9,1 \\
\hline & Y1lda bir & 26 & 10,7 & & 15 gün & 17 & 7,0 \\
\hline & Diğer & 55 & 22,7 & & 1 ay ve daha fazla & 68 & 28,1 \\
\hline & Boş & 13 & 5,4 & & Boş & 10 & 4,1 \\
\hline \multirow{7}{*}{$\begin{array}{l}\text { Konaklama } \\
\text { Yapilan Yer }\end{array}$} & Konaklamıyorum & 57 & 23,6 & \multirow{7}{*}{$\begin{array}{l}\text { Yöreye Birlikte } \\
\text { Gelinen } \\
\text { Kişi/Kişiler }\end{array}$} & Yalnız & 34 & 14,0 \\
\hline & Yazlık & 68 & 28,1 & & Aile & 130 & 53,7 \\
\hline & Pansiyon & 9 & 3,7 & & Akraba & 16 & 6,6 \\
\hline & Kamping & 1 & 0,4 & & Arkadaş & 80 & 33,1 \\
\hline & Otel & 18 & 7,4 & & Tur vb. & 5 & 2,1 \\
\hline & Diğger & 75 & 31,0 & & Diğer & 1 & 0,4 \\
\hline & Boş & 14 & 5,8 & & & & \\
\hline \multirow{5}{*}{$\begin{array}{l}\text { Yöreyi } \\
\text { Ziyaret Etme } \\
\text { sayıs1 }\end{array}$} & İlk & 18 & 7,4 & \multirow{5}{*}{$\begin{array}{l}\text { Yöreyi Ziyaret } \\
\text { Etmeyi Tercih } \\
\text { Ettikleri } \\
\text { Mevsim/ } \\
\text { Mevsimler }\end{array}$} & İlkbahar & 31 & 12,8 \\
\hline & 2. kez & 8 & 3,3 & & Yaz & 224 & 92,6 \\
\hline & 3. kez & 8 & 3,3 & & Sonbahar & 25 & 10,3 \\
\hline & 4.kez ve üzeri & 194 & 80,2 & & $\mathrm{~K}_{1 S ̧}$ & 34 & 24,0 \\
\hline & Boş & 14 & 5,8 & & & & \\
\hline \multirow{14}{*}{$\begin{array}{l}\text { Ziyaretçilerin } \\
\text { Yöreye } \\
\text { Geldikleri İl }\end{array}$} & $\mathrm{IL}$ & $\mathrm{F}$ & $\%$ & \multirow{14}{*}{$\begin{array}{l}\text { Ziyaretçilerin } \\
\text { Yöreye } \\
\text { Geldikleri İl }\end{array}$} & $\dot{\mathrm{I} L}$ & $\mathrm{~F}$ & $\%$ \\
\hline & Adana & 1 & 0,4 & & Izmir & 3 & 1,2 \\
\hline & Almanya & 3 & 1,2 & & Izmit & 4 & 1,7 \\
\hline & Amasya & 1 & 0,4 & & Kastamonu & 1 & 0,4 \\
\hline & Ankara & 22 & 9,1 & & Kayseri & 4 & 1,7 \\
\hline & Antalya & 2 & 0,8 & & Konya & 1 & 0,4 \\
\hline & Antep & 1 & 0,4 & & Mugla & 1 & 0,4 \\
\hline & Bolu & 19 & 7,9 & & Sakarya & 4 & 1,7 \\
\hline & Bursa & 4 & 1,7 & & Sivas & 1 & 0,4 \\
\hline & Düzce & 65 & 26,9 & & Urfa & 1 & 0,4 \\
\hline & Ereğli & 1 & 0,4 & & Yozgat & 2 & 0,8 \\
\hline & Giresun & 11 & 4,5 & & Zonguldak & 3 & 1,2 \\
\hline & Hatay & 2 & 0,8 & & Boş & 12 & 5,0 \\
\hline & Istanbul & 1 & 0,4 & & Toplam & 242 & 100,0 \\
\hline
\end{tabular}

\subsection{Yöre Halkının ve Yerli Turistlerin Memnuniyet Düzeyi}

Katılımcıların Akçakoca'daki turizm alanları açısından memnuniyet düzeylerini belirlemek amacıyla verilen olumlu ve olumsuz yargıların frekans, yüzde dağılımları ve aritmetik ortalamaları Çizelge 3 ve Çizelge 4'de verilmiştir.

- Katılımcıların memnuniyet düzeyini arttıran etmenlerin frekans, yüzde dağılımları ve aritmetik ortalamaları değerlendirildiğinde;

"Doğal çevre ve manzara güzelliği" (AO: 3,6493), "Sessizlik ve huzur" (AO: 3,4928), "Kent stresinden ve günlük yoğunluklardan kurtulmak" (AO: 3,5147), "Sadece ailemle ve dostlarımla baş başa olabilme firsatı" (AO: 3,3863), "Gün batımını izleme olanağı" (AO: 3,7518) yargılarının memnuniyet düzeylerinde etkili olduğu görüş birliği ortaya çıkmaktadır.

"Doğal alanlarda egzersiz olanağı sağlaması" (AO: 2,2519), "Doğal alanlar hakkında bilgi edinmek" (AO: 2,3042), "Çevre temizliğii" (AO: 2,5815), "Su sporları yapabilme" (AO: 2,1852), "Tarihi alanlar hakkında bilgi edinmek" (AO: 2,2635), "Macera ve keşif duygusu (AO: 2,5407) yargılarına katılımcıların verdikleri yanıtlar incelendiğinde ise bu yargıların memnuniyet düzeylerinde etkili olmadığı görülmektedir. 
"Doğal alana kolay ulaşabilme olană̆ı" (AO: 3,0733), "Doğal bir çevrede boş zaman değerlendirmek" (AO: 3,0796), "Mevcut plajlar ve olanakları" (AO: 3,0662) yargılarının aritmetik ortalamaları, frekans ve yüzde dağılımları incelendiğinde; bu yargıların katılımcıların memnuniyet düzeylerinde kısmen etkili, kısmen etkisiz olduğu tespit edilmektedir. "Şenlik ve Festivallerin düzenlenmesi" (AO: 2,7916), "Tatil ve eğlence maliyetlerinin düşük olması" (AO: 2,8407) yargılarının aritmetik ortalamaları ile frekans ve yüzde dağılımları incelendiğinde ise; katılımcıların verdikleri yanıtların "etkili değil”" ile "kararsız" seçenekleri arasında bir değer olarak karşımıza çıktığı belirlenmektedir (Çizelge 3).

Çizelge 3. Yöre halkı ve yerli turistlerin memnuniyet düzeyini arttıran etmenlerin frekans ve yüzde dağılımları.

\begin{tabular}{|c|c|c|c|c|c|c|c|c|c|c|c|c|c|}
\hline \multirow[b]{2}{*}{ Etmenler (Yargılar) } & \multirow[b]{2}{*}{$\mathrm{N}$} & \multirow[b]{2}{*}{$\begin{array}{c}\text { Arit.€Ort. } \\
\overline{\mathrm{X}}\end{array}$} & \multirow[b]{2}{*}{ S.S } & \multicolumn{2}{|c|}{  } & \multicolumn{2}{|c|}{ 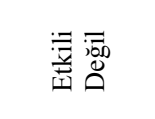 } & \multicolumn{2}{|c|}{ 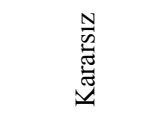 } & \multicolumn{2}{|c|}{ 咅 } & \multicolumn{2}{|c|}{ 商涪 } \\
\hline & & & & $\mathrm{F}$ & $\%$ & $\mathrm{~F}$ & $\%$ & $\mathrm{~F}$ & $\%$ & $\mathrm{~F}$ & $\%$ & $\mathrm{~F}$ & $\%$ \\
\hline $\begin{array}{l}\text { Doğal çevre ve manzara } \\
\text { güzelliği }\end{array}$ & 422 & 3,6493 & 1,11787 & 17 & 3,9 & 40 & 9,2 & 141 & 32,4 & 100 & 23,0 & 124 & 28,5 \\
\hline $\begin{array}{l}\text { Doğal alana kolay ulaşabilme } \\
\text { olanağ }\end{array}$ & 416 & 3,0793 & 1,14111 & 31 & 7,1 & 105 & 24,1 & 137 & 31,5 & 86 & 19,8 & 57 & 13,1 \\
\hline $\begin{array}{l}\text { Doğal alanlarda egzersiz } \\
\text { olanağ1 sağlaması }\end{array}$ & 401 & 2,2519 & 1,08577 & 117 & 26,9 & 132 & 30,3 & 101 & 23,2 & 36 & 8,3 & 15 & 3,4 \\
\hline $\begin{array}{l}\text { Doğal bir çevrede boş zaman } \\
\text { değerlendirmek }\end{array}$ & 402 & 3,0796 & 1,17481 & 45 & 10,3 & 75 & 17,2 & 137 & 31,5 & 93 & 21,4 & 52 & 12,0 \\
\hline $\begin{array}{l}\text { Doğal alanlar hakkında bilgi } \\
\text { edinmek }\end{array}$ & 401 & 2,3042 & 1,15421 & 116 & 26,7 & 133 & 30,6 & 88 & 20,2 & 42 & 9,7 & 22 & 5,1 \\
\hline Sessizlik ve huzur & 414 & 3,4928 & 1,22670 & 29 & 6,7 & 63 & 14,5 & 106 & 24,4 & 107 & 24,6 & 109 & 25,1 \\
\hline Macera ve keşif duygusu & 405 & 2,5407 & 1,34107 & 120 & 27,6 & 95 & 21,8 & 85 & 19,5 & 61 & 14,0 & 44 & 10,1 \\
\hline $\begin{array}{l}\text { Kent stresinden ve günlük } \\
\text { yoğunluklardan kurtulmak }\end{array}$ & 408 & 3,5147 & 1,24011 & 32 & 7,4 & 52 & 12,0 & 112 & 25,7 & 98 & 22,5 & 114 & 26,2 \\
\hline Çevre temizliği & 411 & 2,5815 & 1,36687 & 120 & 27,6 & 89 & 20,5 & 101 & 23,2 & 45 & 10,3 & 56 & 12,9 \\
\hline Yeni insanlarla tanışmak & 403 & 2,3672 & 1,24154 & 126 & 29,0 & 106 & 24,4 & 102 & 23,4 & 35 & 8,0 & 34 & 7,8 \\
\hline $\begin{array}{l}\text { Büyük gruplarla eğlenceli bir } \\
\text { ortamda bulunma firsat1 }\end{array}$ & 405 & 2,5654 & 1,34929 & 115 & 26,4 & 100 & 23,0 & 85 & 19,5 & 56 & 12,9 & 49 & 11,3 \\
\hline $\begin{array}{l}\text { Sadece ailem ve dostlarımla } \\
\text { baş başa olabilme firsatı }\end{array}$ & 409 & 3,3863 & 1,32006 & 48 & 11,0 & 51 & 11,7 & 117 & 26,9 & 81 & 18,6 & 112 & 25,7 \\
\hline $\begin{array}{l}\text { Çocukların iyi zaman } \\
\text { geçireceği mekânlar } \\
\text { bulunması }\end{array}$ & 403 & 2,4491 & 1,34729 & 133 & 30,6 & 96 & 22,1 & 76 & 17,5 & 56 & 12,9 & 42 & 9,7 \\
\hline $\begin{array}{l}\text { Değişik spor aktivitelerinin } \\
\text { yapılabilmesi }\end{array}$ & 400 & 2,0525 & 1,13929 & 159 & 36,6 & 129 & 29,7 & 66 & 15,2 & 24 & 5,5 & 22 & 5,1 \\
\hline Sportif balıkçlık yapabilme & 400 & 2,1875 & 1,31212 & 173 & 39,8 & 82 & 18,9 & 79 & 18,2 & 29 & 6,7 & 37 & 8,5 \\
\hline Su sporları yapabilme & 405 & 2,1852 & 1,24590 & 165 & 37,9 & 91 & 20,9 & 85 & 19,5 & 37 & 8,5 & 27 & 6,2 \\
\hline Mevcut plajlar ve olanakları & 408 & 3,0662 & 1,16376 & 36 & 8,3 & 98 & 22,5 & 134 & 30,8 & 83 & 19,1 & 57 & 13,1 \\
\hline $\begin{array}{l}\text { Tarihi alanlar hakkında bilgi } \\
\text { edinmek }\end{array}$ & 406 & 2,2635 & 1,46801 & 123 & 28,3 & 139 & 32,0 & 93 & 21,4 & 33 & 7,6 & 17 & 3,9 \\
\hline $\begin{array}{l}\text { Yöresel ve folklorik } \\
\text { özellikleri tanıma firsatı }\end{array}$ & 405 & 2,2815 & 1,16457 & 121 & 27,8 & 137 & 31,5 & 83 & 19,1 & 40 & 9,2 & 24 & 5,5 \\
\hline $\begin{array}{l}\text { Şenlik ve festivallerin } \\
\text { düzenlenmesi }\end{array}$ & 403 & 2,7916 & 1,31248 & 86 & 19,8 & 89 & 20,5 & 101 & 23,2 & 77 & 17,7 & 50 & 11,5 \\
\hline Gün batımını izleme olanağı & 411 & 3,7518 & 1,26171 & 30 & 6,9 & 39 & 9,0 & 93 & 21,4 & 90 & 20,7 & 159 & 36,6 \\
\hline $\begin{array}{l}\text { Tatil ve eğlence } \\
\text { maliyetlerinin düşük olması }\end{array}$ & 408 & 2,8407 & 1,40256 & 90 & 20,7 & 95 & 21,8 & 86 & 19,8 & 64 & 14,7 & 73 & 16,8 \\
\hline
\end{tabular}




\section{A.Altanlar ve G.Akıncı Kesim}

- Katılımcıların memnuniyet düzeyini azaltan etmenlerin frekans, yüzde dağılımları ve aritmetik ortalamaları değerlendirildiğinde;

"Yaz aylarında oluşan nüfus artışı" yargısına \% 42,1'inin "hiç sorun değil", "Plajlarda çok fazla kullanım yoğunluğu" yargısına \% 25,3'ünün, "Kamplarda ve piknik alanlarında kullanım yoğunluğu" yargısına \% 29,9'unun, "Araç sayısının fazlalı̆̆ 1 ve trafik sorunları" yargısına \% 26,9'unun, "Yaz aylarında gürültüde artış olması" yargısına \% 27,8'inin, "Doğal alanlarda kitle iletişim araçlarının insanları rahatsız etmesi" yargısına \% 26,2'sinin "sorun değil" yanıtlarını verdikleri belirlenmiştir. Katılımcıların verdikleri yanıtların aritmetik ortalamaları da incelendiğinde; bu yargıların katılımcıların memnuniyetlerini olumsuz etkilemediği görülmektedir. "Yollar, sahil, piknik ve kamp alanlarındaki çöpler" yargısına \% 42,3'ünün, "Plajlarda tuvalet, soyunma kabini ve duş yetersizliği" yargısına \% 52'sinin, "Doğal ve tarihi güzellikler hakkında tanıtım ve reklam eksikliği”" yargısına \% 32 'sinin "Doğal ve tarihi güzellikleri tanıtan tur ve organizasyonların olmaması" yargısına \% 34,5'inin, "Doğal alanlara ulaşım zorluğu ve toplu taşıma araçlarının olmamasi/yetersizliği" yargısına \% 24,6'sının, "Yolların bakımsızlığı" yargısına katılımcıların \% 31,3'ünün, "Otopark eksikliği ve yollara araçların park etmesi" yargısına \% 35,4'ünün, "Yapı yoğunluğu ve plansız yapılaşma" yargısına \% 30,8'i "Yeterli ve kaliteli tesis eksikliği" yargısına \% 31,7'sinin, "Spor eğlence dinlenme tesisi gibi yerlerin yeterli olmaması" yargısına \% 33,3'ünün, "Yeterli alt yapının olmaması" yargısına \% 41,4'ünün, "Düzenlenmiş kırsal ve kentsel alanlarda bakım çalışmalarının yapılmaması ya da yetersiz kalması" yargısına \% 32'sinin, "Kanalizasyonların arıtmasız olarak akarsu ve denize bırakılmaları" yargısına \% 56,6'sının, "Çöp ve diğer katı atıklarla denizin kirletilmesi” yargısına \% 63,4'ünün, "İklimsel faktörlerden dolayı deniz mevsiminin kısa olması" yargısına \% 29,2'sinin, "Zararlı böcekler ve başıboş hayvanlar" yargısına \% 27,1'inin "çok sorun" yanıtlarını verdikleri görülmektedir. Katılımcıların verdikleri yanıtların aritmetik ortalaması incelendiğinde ise; yöre halkı ve yerli turistlerin bu yargıları sorun olarak gördükleri ortaya çıkmıştır (Çizelge 4).

Çizelge 4. Yöre halkı ve yerli turistlerin memnuniyet düzeyini azaltan etmenlerin frekans ve yüzde dağılımları.

\begin{tabular}{|c|c|c|c|c|c|c|c|c|c|c|c|c|c|}
\hline \multirow{2}{*}{ Etmenler (Yargilar) } & \multirow[b]{2}{*}{$\mathrm{N}$} & \multirow[b]{2}{*}{$\begin{array}{c}\text { Ort } \\
\bar{X}\end{array}$} & \multirow[b]{2}{*}{ S.s } & \multicolumn{2}{|c|}{ 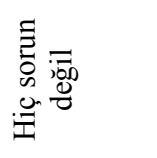 } & \multicolumn{2}{|c|}{ 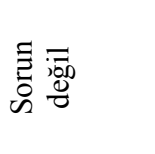 } & \multicolumn{2}{|c|}{ 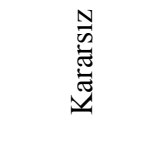 } & \multicolumn{2}{|l|}{ 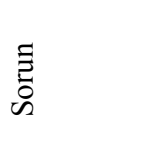 } & \multicolumn{2}{|c|}{ 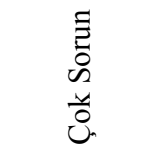 } \\
\hline & & & & $\mathrm{F}$ & $\%$ & $\mathrm{~F}$ & $\%$ & $\mathrm{~F}$ & $\%$ & $\mathrm{~F}$ & $\%$ & $\mathrm{~F}$ & $\%$ \\
\hline $\begin{array}{l}\text { Yaz aylarında oluşan } \\
\text { nüfus artışı }\end{array}$ & 414 & 2,1473 & 1,30376 & 183 & 42,1 & 92 & 21,1 & 71 & 16,3 & 31 & 7,1 & 37 & 8,5 \\
\hline $\begin{array}{l}\text { Plajlarda çok fazla } \\
\text { kullanım yoğunluğu }\end{array}$ & 414 & 2,5628 & 1,29243 & 106 & 24,4 & 110 & 25,3 & 104 & 23,9 & 47 & 10,8 & 47 & 10,8 \\
\hline $\begin{array}{l}\text { Kamplarda ve piknik } \\
\text { alanlarında kullanım }\end{array}$ & 412 & 2,4248 & 1,20690 & 108 & 24,8 & 130 & 29,9 & 97 & 22,3 & 45 & 10,3 & 32 & 7,4 \\
\hline $\begin{array}{l}\text { Yönlendirme ve uyarı } \\
\text { levhaları eksikliği }\end{array}$ & 406 & 2,9778 & 1,37598 & 79 & 18,2 & 71 & 16,3 & 116 & 26,7 & 60 & 13,8 & 80 & 18,4 \\
\hline $\begin{array}{l}\text { Yollar, sahil, piknik ve } \\
\text { kamp alanlarındaki }\end{array}$ & 414 & 3,9106 & 1,17448 & 16 & 3,7 & 36 & 8,3 & 101 & 23,2 & 77 & 17,7 & 184 & 42,3 \\
\hline $\begin{array}{l}\text { Plajlarda tuvalet, } \\
\text { soyunma kabini ve duş }\end{array}$ & 412 & 4,1942 & 1,04923 & 9 & 2,1 & 21 & 4,8 & 77 & 17,7 & 79 & 18,2 & 226 & 52,0 \\
\hline $\begin{array}{l}\text { Doğal ve tarihi } \\
\text { güzellikler hakkında } \\
\text { tanıtım ve reklâm } \\
\text { eksikliği }\end{array}$ & 416 & 3,6058 & 1,25664 & 28 & 6,4 & 55 & 12,6 & 109 & 25,1 & 85 & 19,5 & 139 & 32,0 \\
\hline $\begin{array}{l}\text { Doğal ve tarihi } \\
\text { güzellikleri tanıtan tur } \\
\text { ve organizasyonların } \\
\text { olmaması }\end{array}$ & 413 & 3,5884 & 1,34744 & 38 & 8,7 & 60 & 13,8 & 86 & 19,8 & 79 & 18,2 & 150 & 34,5 \\
\hline
\end{tabular}


Çizelge 4 Devamı. Yöre halkı ve yerli turistlerin memnuniyet düzeyini azaltan etmenlerin frekans ve yüzde dağılımları.

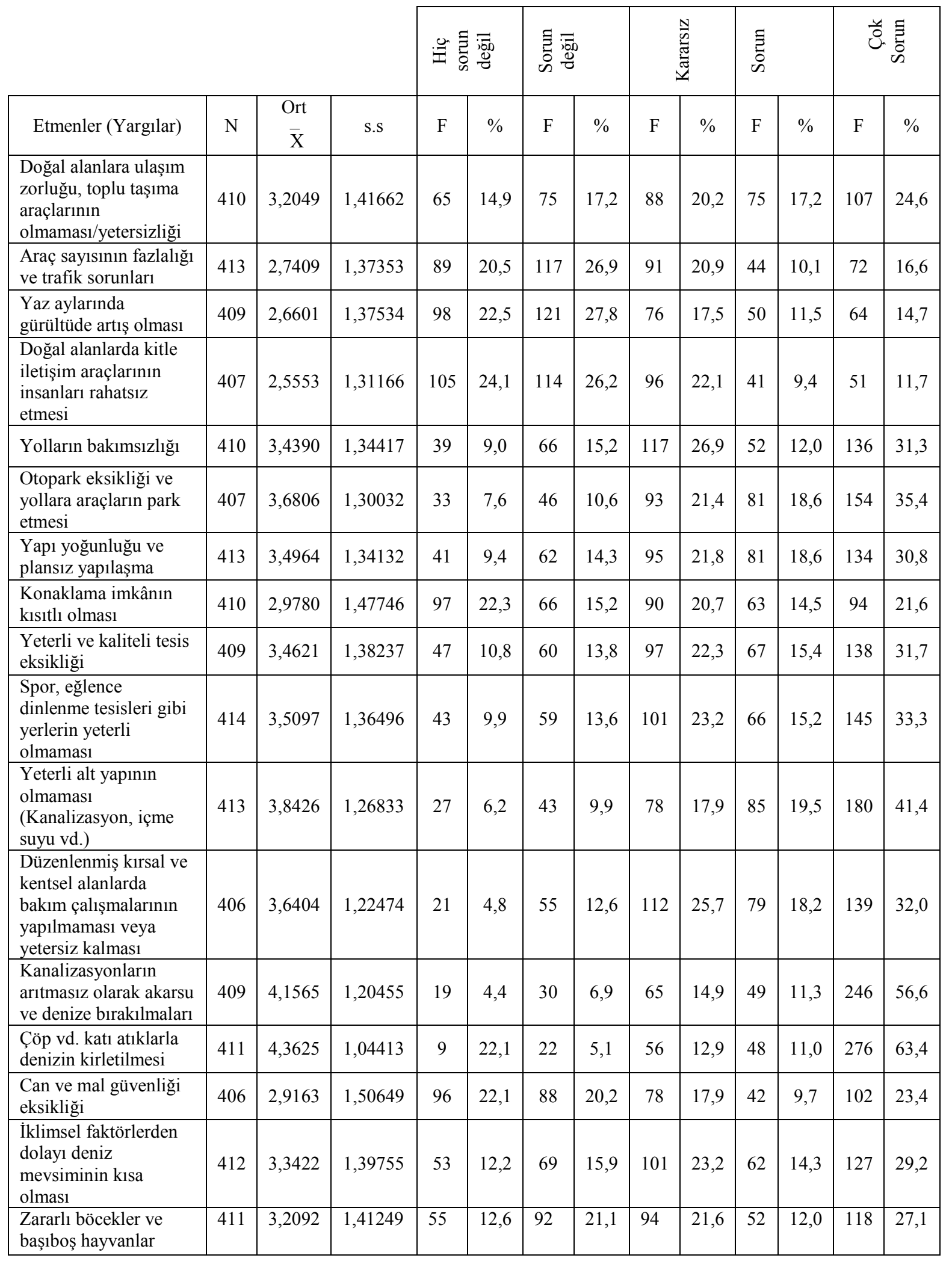




\section{A.Altanlar ve G.Akıncı Kesim}

Katılımcıların "Konaklama olanaklarının kısıtlı olması" yargısına \% 22,3'ü "hiç sorun değil", $\% 15,2$ 'si sorun değil, \%20,7'si kararsız, \%14,5'si sorun ve \% 21,6's1 "çok sorun" yanıtını vermişlerdir. Katılımcıların verdikleri yanıtların aritmetik ortalaması ise 2,9780 olarak bulunmuştur. "Can ve mal güvenliği eksikliği" yargısına \% 22,1'i "hiç sorun değil", \%20,2'si "sorun değil", \%17,9'u "kararsız", \%9,7'si sorun \%23,4'ü “çok sorun” yanıtını vermişlerdir. Katılımcıların verdikleri yanıtların aritmetik ortalaması 2,9163 olarak bulunmuştur. Elde edilen veriler ışığında her iki yargı için de genel görüşün kararsız bir eğilim gösterdiği ortaya çıkmaktadır (Çizelge 4).

3.4. Yöre Halkı ve Yerli Turistlerin Memnuniyet Düzeyini Belirleyen Etmenlerin Sinıflandirılması

Ankete katılan yöre halkı ve yerli turistlerin memnuniyet düzeylerinde aynı boyutu ölçen yargılara verilen değişkenlerin gruplandırılabilmesi amacıyla faktör analizi yapıllmış ve güvenilirlik analizi ile test edilmiştir. Elde edilen istatistiki veriler Çizelge 5 ve Çizelge 6'da yer almaktadır.

- Yöre halkı ve yerli turistlerin memnuniyet düzeyini arttıran etmenlerin sınıflandırılması

Katılımcıların memnuniyet düzeylerini arttıran 22 yargıya verdikleri yanıtlara ilişkin veriler faktör analizi ile gruplandırıldığında, üç adet faktör tespit edilmiştir (Çizelge 5). Memnuniyet düzeyini arttıran kriterleri belirlemek amaciyla verilen 22 adet yargıdan 10 adeti birinci faktöre, 10 adeti ikinci faktöre, 2 adeti ise üçüncü faktöre dahil olmuştur. Faktör 1' de yer alan kriterlerin hepsinde bir katılım istediği olduğu düşünülerek "doğal alanlardan aktif olarak faydalanma", faktör 2'de yer alan kriterlerin çoğunun ortak özelliğinin "doğal alanlardan pasif olarak faydalanmak", faktör 3' de yer alan kriterlerin hepsinin ortak özelliğinin de "sosyal aktivite odaklı fayda sağlama isteği”" olduğu görülmektedir.

Çizelge 5. Yöre halkı ve yerli turistlerin memnuniyet düzeyini arttıran etmenlerin sınıflandırılması.

\begin{tabular}{|c|c|c|c|}
\hline Etmenler (Yargilar) & Faktör 1 & Faktör 2 & Faktör 3 \\
\hline Doğal alanlarda egzersiz olanağı sağlaması & 0,534 & & \\
\hline Doğal alanlar hakkında bilgi edinmek, & 0,457 & & \\
\hline Macera ve keşif duygusu, & 0,493 & & \\
\hline Çocukların iyi zaman geçireceği mekânlar bulunması, & 0,605 & & \\
\hline Değişik spor aktivitelerinin yapılabilmesi, & 0,678 & & \\
\hline Sportif balıkçılık yapabilme, & 0,691 & & \\
\hline Su sporlar1 yapabilme, & 0,580 & & \\
\hline Tarihi alanlar hakkında bilgi edinmek, & 0,473 & & \\
\hline Yöresel ve folklorik özellikleri tanıma firsatı, & 0,560 & & \\
\hline Şenlik ve festivallerin düzenlenmesi & 0,502 & & \\
\hline Doğal çevre ve manzara güzelliği, & & 0,728 & \\
\hline Doğal alana kolay ulaşabilme olanağı, & & 0,679 & \\
\hline Kent stresinden ve günlük yoğunluklardan kurtulmak, & & 0,534 & \\
\hline Sessizlik ve huzur, & & 0,594 & \\
\hline Sadece ailem ve dostlarımla baş başa olma firsatı, & & 0,537 & \\
\hline Çevre temizliği, & & 0,466 & \\
\hline Mevcut plajlar ve olanakları & & 0,503 & \\
\hline Gün batımı izleme olanağ 1 & & 0,367 & \\
\hline Tatil ve eğlence maliyetlerinin düşük olması, & & 0,459 & \\
\hline Yeni insanlarla tanışmak, & & & 0,732 \\
\hline Büyük gruplarla eğlenceli bir ortamda bulunma firsat1, & & & 0,794 \\
\hline Genel Ortalama & 2,3181 & 3,2620 & 2,9315 \\
\hline Alfa & 0,8018 & 0,7898 & 0,7098 \\
\hline Varyans $(\%)$ & 16,534 & 15,832 & 9,517 \\
\hline $\begin{array}{l}\text { F1: Doğal Alanlardan Aktif Olarak Faydalanma İsteği; } \\
\text { F2: Doğal Alanlardan Pasif Olarak Faydalanma İsteği; } \\
\text { F3: Sosyal Aktivite Odaklı Fayda Sağlama İsteği }\end{array}$ & & & \\
\hline
\end{tabular}


- Yöre halk1 ve yerli turistlerin memnuniyet düzeyini azaltan etmenlerin sinıflandırılmas1

Katılımcıların memnuniyet düzeylerini azaltan 25 yargıya verdikleri yanıtlara ilişkin veriler faktör analizi ile gruplandırıldığında ise, dört adet faktör tespit edilmiştir. Tespit edilen faktörlere ilişkin faktör yükleri ve güvenilirlik analizi sonuçları Çizelge 6'da yer almaktadır. Memnuniyet düzeyini azaltan kriterleri belirlemek amacıyla verilen 25 adet yargıdan 10 adeti birinci faktöre, 8 adeti ikinci faktöre, 3 adeti üçüncü faktöre, 4 adeti dördüncü faktöre dahil olmuştur. Faktör 1'de yer alan kriterlerin hepsinin "donatı ve konaklama eksikliği”, faktör 2'de yer alan kriterlerin hepsinin ortak özelliğinin "alt yapı bakım ve onarım eksikliği”, faktör 3' de yer alan kriterlerin hepsinin ortak özelliğinin "taşıma kapasitesinin aşılması" ve son olarak faktör 4' de yer alan kriterlerin hepsinin ortak özelliğinin de "görüntü ve gürültü kirliliği” olduğu görülmektedir.

Çizelge 6. Yöre halkı ve yerli turistlerin memnuniyet düzeyini azaltan etmenlerin sınıflandırılması

\begin{tabular}{|c|c|c|c|c|}
\hline Etmenler (Yargilar) & $\begin{array}{c}\text { Faktör } \\
1\end{array}$ & $\begin{array}{c}\text { Faktör } \\
2\end{array}$ & $\begin{array}{c}\text { Faktör } \\
3\end{array}$ & $\begin{array}{c}\text { Faktör } \\
4\end{array}$ \\
\hline Yönlendirme ve uyarı levhaları eksikliği & 0,512 & & & \\
\hline Plajlarda tuvalet, soyunma kabini ve duş yetersizliği, & 0,510 & & & \\
\hline Doğal ve tarihi güzellikler hakkında tanıtım ve reklâm eksikliği, & 0,671 & & & \\
\hline $\begin{array}{l}\text { Doğal ve tarihi güzellikleri tanıtan tur ve organizasyonların } \\
\text { olmaması, }\end{array}$ & 0,682 & & & \\
\hline $\begin{array}{l}\text { Doğal alanlara ulaşım zorluğu, toplu taşıma araçlarının } \\
\text { olmaması / yetersizliği, }\end{array}$ & 0,700 & & & \\
\hline Yolların bakımsızlığı & 0,408 & & & \\
\hline Yap1 yoğunluğu ve plansız yapılaşma & 0,466 & & & \\
\hline Konaklama imkânın kısıtlı olması, & 0,769 & & & \\
\hline Yeterli ve kaliteli tesis eksikliği, & 0,773 & & & \\
\hline Spor, eğlence dinlenme tesisleri gibi yerlerin yeterli olmamas1, & 0,756 & & & \\
\hline $\begin{array}{l}\text { Yollar, sahil, piknik ve kamp alanlarındaki çöpler, } \\
\text { yapılmaması veya yetersiz kalması, }\end{array}$ & & 0,576 & & \\
\hline Yeterli alt yapının olmaması (Kanalizasyon, içme suyu vd.), & & 0,638 & & \\
\hline $\begin{array}{l}\text { Düzenlenmiş kırsal ve kentsel alanlarda bakım çalışmalarının } \\
\text { yapılmaması }\end{array}$ & & 0,556 & & \\
\hline $\begin{array}{l}\text { Kanalizasyonların arıtmasız olarak akarsu ve denize } \\
\text { bırakılmaları, }\end{array}$ & & 0,717 & & \\
\hline Çöp vd. katı atıklarla denizin kirletilmesi, & & 0,808 & & \\
\hline Can ve mal güvenliği eksikliği & & 0,414 & & \\
\hline İklimsel faktörlerden dolayı deniz mevsiminin kısa olması & & 0,440 & & \\
\hline Zararlı böcekler ve başıboş hayvanlar & & 0,460 & & \\
\hline Yaz aylarında oluşan nüfus artışı, & & & 0,751 & \\
\hline Plajlarda çok fazla kullanım yoğunluğu, & & & 0,825 & \\
\hline Kamplarda ve piknik alanlarında kullanım yoğunluğu, & & & 0,778 & \\
\hline Araç sayısının fazlalığı ve trafik sorunları, & & & & 0,360 \\
\hline Yaz aylarında gürültüde artış olması, & & & & 0,601 \\
\hline $\begin{array}{l}\text { Doğal alanlarda kitle iletişim araçlarının insanları rahatsız } \\
\text { etmesi }\end{array}$ & & & & 0,565 \\
\hline Otopark eksikliği ve yollara araçların park etmesi, & & & & 0,606 \\
\hline Genel Ortalama & 3,4659 & 3,6963 & 2,3751 & 2,8962 \\
\hline Alfa & 0,8871 & 0,8062 & 0,8379 & 0,7686 \\
\hline Varyans $(\%)$ & 19,494 & 15,229 & 11,475 & 10,259 \\
\hline \multicolumn{5}{|l|}{$\begin{array}{l}\text { F1:Donatı ve konaklama eksikliği; } \\
\text { F2:Alt yapı, bakım ve onarım eksikliği; } \\
\text { F3: Taşıma kapasitesinin aş1lması; } \\
\text { F 4: Gürültü ve görüntü kirliliği }\end{array}$} \\
\hline
\end{tabular}


3.5. Yöre Halkı ve Yerli Turistlerin Demografik Özellikleri ile Memnuniyetlerini Belirleyen Etmenlerin Karşılaştırılması

- Yöre halk1 ve yerli turistlerin demografik özellikleri ile memnuniyetlerini arttıran etmenlerin karşılaştırılması;

Yöre halkı ve yerli turistlerin demografik özellikleri (eğitim düzeyi, yaş dağılımı, gelir dağılımı) ile Akçakoca'daki turizm alanları açısından memnuniyetlerini arttıran eylemleri belirleyen etmenlerin gruplandırılması sonucu elde edilen "doğal alanlardan aktif olarak faydalanma isteği”, "doğal alanlardan pasif olarak faydalanma isteği” ve " sosyal aktivite odaklı fayda sağlama isteği” faktörleri arasında anlamlı bir farklılık bulunup bulunmadığına ilişkin, Bağımsız Örneklemler için Tek-Faktörlü Varyans Analizi (One-Way ANOVA) ve Bağımsız Örneklemler için T Testi (Independent- Samples T Test) analizleri yapılmıştır. Ayrıca anlamlı bir farklılık söz konusu ise, bu farklılı̆̆ın ne yönde olduğu da araştırma kapsamında yorumlanmıştır.

Ankete katılan katılımcıların, eğitim düzeyleri ile faktör gruplarına verdikleri yanıtlar arasında anlamlı bir farklılık bulunmadığı tespit edilmiştir. Sonuç olarak, katılımcıların farklı eğitim düzeylerinde olmalarının faktör gruplarına verdikleri yanıtlar üzerinde herhangi bir etkisinin bulunmadığı ve bu faktörlere verdikleri yanıtlara ilişkin ortalamaların ise birbirlerine yakın değerler içerdiği görülebilmektedir. Benzer bir şekilde yaş dağılımı ve katılımcıların faktör gruplarına verdikleri yanıtlara ilişkin istatistiki veriler incelendiğinde; aralarında anlamlı bir farklılık bulunmadığı ve farklı yaş gruplarında olmalarının, faktörlere ilişkin belirttikleri görüşler üzerinde herhangi bir etkisinin bulunmadı̆̆ görülmektedir (Altanlar, 2007).

Katılımcıların gelir düzeyleri ile faktör grupları arasındaki ilişki incelendiğinde ise, katılımcıların farklı gelir gruplarında olmalarının "doğal alanlardan aktif olarak faydalanma isteği" ve "doğal alanlardan pasif olarak faydalanma isteği" faktörlerine verdikleri yanttlar üzerinde herhangi bir etkisinin olmadığı ancak farklı gelir gruplarında katılımcıların "sosyal aktivite odaklı fayda sağlama isteği" faktörüne ilişkin yargılara verdikleri yanıtlar arasında anlamlı bir farklılık olduğu görülebilmektedir. "Sosyal aktivite odaklı fayda sağlama isteği" faktörüne verilen yanıtlara ilişkin ortalamalar incelendiğinde; en memnun kullanıcıların 2001 TL ve üstü gelir düzeyine sahipken, 15012000 TL arası gelir düzeyine sahip olanların nispeten daha az memnun oldukları belirlenmiştir (Çizelge 7).

Çizelge 7. Yöre halkı ve yerli turistlerin memnuniyetlerini arttıran etmenlerin gelir dağılımı ile karşılaştırılması.

\begin{tabular}{|c|c|c|c|c|c|c|}
\hline Faktörler & Gelir Dağılımı & $\mathrm{N}$ & $\begin{array}{l}\text { A.O. } \\
\bar{X}\end{array}$ & s.s. & $\mathrm{F}$ & $\mathrm{P}$ \\
\hline \multirow{5}{*}{$\begin{array}{l}\text { Doğal Alanlardan Aktif } \\
\text { Olarak Faydalanma İsteği }\end{array}$} & 500den az & 113 & 2,2375 & 0,76410 & \multirow{5}{*}{1,962} & \multirow{5}{*}{0,100} \\
\hline & $500-1000$ & 130 & 2,2162 & 0,68544 & & \\
\hline & $1001-1500$ & 66 & 2,4124 & 0,83339 & & \\
\hline & $1501-2000$ & 33 & 2,3144 & 0,88075 & & \\
\hline & 2001 ve üstü & 30 & 2,5907 & 0,92853 & & \\
\hline \multirow{5}{*}{$\begin{array}{l}\text { Doğal Alanlardan Pasif } \\
\text { Olarak Faydalanma İsteği }\end{array}$} & 500den az & 114 & 3,1170 & 0,73854 & \multirow{5}{*}{1,041} & \multirow{5}{*}{0,386} \\
\hline & $500-1000$ & 135 & 3,2202 & 0,78608 & & \\
\hline & $1001-1500$ & 67 & 3,2400 & 0,78866 & & \\
\hline & $1501-2000$ & 33 & 3,3101 & 0,67487 & & \\
\hline & 2001 ve üstü & 32 & 3,3919 & 0,81077 & & \\
\hline \multirow{5}{*}{$\begin{array}{l}\text { Sosyal Aktivite Odaklı } \\
\text { Fayda Sağlama İsteği }\end{array}$} & 500den az & 113 & 2,5796 & 1,24923 & \multirow{5}{*}{2,493} & \multirow{5}{*}{$0,043^{*}$} \\
\hline & $500-1000$ & 128 & 2,3945 & 1,10056 & & \\
\hline & $1001-1500$ & 66 & 2,3182 & 0,92252 & & \\
\hline & $1501-2000$ & 33 & 2,1667 & 1,20977 & & \\
\hline & 2001 ve üstü & 29 & 2,9310 & 1,12380 & & \\
\hline
\end{tabular}


Katılımcıların Akçakoca'da ikamet edip etmeme durumları ile faktör gruplarına verdikleri yanıtlara ilişkin istatistiki veriler incelendiğinde; ikamet durumu ile "doğal alanlardan pasif olarak faydalanma isteği" ve "sosyal aktivite odaklı fayda sağlama isteği" faktörlerinde arasında anlamlı bir farkl1lık olduğu görülebilmektedir. Buna göre, Akçakoca'ya gelen yerli turistlerin bu iki faktör grubuna ilişkin görüşlerinin yöre halkının görüşlerine göre daha olumlu olduğu görülmektedir (Çizelge 8).

Çizelge 8. Yöre halkı ve yerli turistlerin memnuniyetlerini arttıran etmenlerin ikametgah durumu ile karşılaştırılması.

\begin{tabular}{|c|c|c|c|c|c|c|c|}
\hline Faktörler & İkamet Durumu & $\mathrm{N}$ & $\begin{array}{l}\text { A.O. } \\
\bar{X}\end{array}$ & s.s & s.d & $\mathrm{T}$ & $\mathrm{p}$ \\
\hline \multirow{2}{*}{$\begin{array}{l}\text { Doğal Alanlardan Aktif Olarak } \\
\text { Faydalanma İsteği }\end{array}$} & $\begin{array}{l}\text { Akçakoca' da } \\
\text { yaşıyorum }\end{array}$ & 183 & 2,2593 & 0,76392 & \multirow{2}{*}{411} & \multirow{2}{*}{0,792} & \multirow{2}{*}{0,429} \\
\hline & $\begin{array}{l}\text { Akçakoca' da } \\
\text { yaşamıyorum }\end{array}$ & 230 & 2,3200 & 0,78068 & & & \\
\hline \multirow{2}{*}{$\begin{array}{l}\text { Doğal Alanlardan Pasif Olarak } \\
\text { Faydalanma İsteği }\end{array}$} & $\begin{array}{l}\text { Akçakoca' da } \\
\text { yaşıorum }\end{array}$ & 186 & 3,0875 & 0,82659 & \multirow{2}{*}{420} & \multirow{2}{*}{2,801} & \multirow{2}{*}{$* * 0,005$} \\
\hline & $\begin{array}{l}\text { Akçakoca' da } \\
\text { yaşamıyorum }\end{array}$ & 236 & 3,2969 & 0,70803 & & & \\
\hline \multirow{2}{*}{$\begin{array}{l}\text { Sosyal Aktivite Odaklı Fayda Sağlama } \\
\text { İsteği }\end{array}$} & $\begin{array}{l}\text { Akçakoca' da } \\
\text { yaşıorum }\end{array}$ & 180 & 2,2667 & 1,05094 & \multirow{2}{*}{406} & \multirow{2}{*}{3,151} & \multirow{2}{*}{$* * 0,002$} \\
\hline & $\begin{array}{l}\text { Akçakoca' da } \\
\text { yaşamıyorum }\end{array}$ & 228 & 2,6140 & 1,14679 & & & \\
\hline
\end{tabular}

${ }^{*} \mathrm{p}<0,05, * * \mathrm{p}<0,005, * * * \mathrm{p}<0,001$, A.O: Aritmetik Ortalama

- Yöre halk1 ve yerli turistlerin demografik özellikleri ile memnuniyetlerini azaltan etmenlerin karşılaştırılması

Yöre halkı ve yerli turistlerin demografik özellikleri (eğitim düzeyleri, yaş dağılımları ve gelir düzeyleri) ile memnuniyetlerini azaltan dört faktör arasında anlamlı bir farklılık bulunup bulunmadığına ilişkin, Bağımsız Örneklemler İçin Tek-Faktörlü Varyans Analizi (One-Way ANOVA) kullanılmıştır. Ankete katılan katılımcıların demografik özellikleri ile "donatı ve konaklama eksikliği", "alt yapı bakım ve onarım eksikliği”,"taşıma kapasitesinin aşılması" ve "gürültü ve görüntü kirliliği”’faktörleri karşılaştırıldığında; eğitim düzeyleri ile faktör gruplarına verilen yanıtlar arasında anlamlı bir farklılık bulunmadığı tespit edilmiş̧tir (Altanlar, 2007).

Ankete katılan katılımcıların yaş grupları ile bu dört faktör arasındaki ilişki karşılaştırıldığında ise; "taşıma kapasitesinin aşılması" faktörüne verdikleri yanıtlara ilişkin aralarında anlamlı bir farklılık bulunmadığı tespit edilirken, "donatı, konaklama ve tanıtım eksikliği", "altyapı, bakım ve onarım eksikliği" ve "gürültü ve görüntü kirliliği" faktörlerine verilen yanıtlara ilişkin veriler incelendiğinde ise aralarında anlamlı bir farklılık bulunduğu görülmektedir. Elde edilen bu verilere ilişkin ortalamalar incelendiğinde; Akçakoca'daki turizm alanlarında donatı, konaklama ve tanıtım eksikliğinin 30-39 yaş arasındaki katılımcıların memnuniyetsizliğini daha fazla arttırırken, 50-59 yaş aralığında olan katılımcıların memnuniyetsizliğini nispeten daha az arttırdığı yargısına varılmaktadır. Yine Akçakoca'daki turizm alanlarındaki altyapı, bakım ve onarım eksikliğinin 30-39 yaş arasındaki yöre halk1 ve yerli turistlerin memnuniyetsizliğini çok fazla arttırırken, 19 ve altı yaş grubunda bulunan yöre halk1 ve yerli turistlerin memnuniyetsizliğinin nispeten daha az olduğu belirlenmiştir. Son olarak, ankete katılan yöre halkı ve yerli turistlerden 40-49 yaş arasında bulunanlar gürültü ve görüntü kirliliğinden daha fazla rahatsızlık duyarken, 19 ve altı yaş grubundaki katılımcıların daha az rahatsızlık duydukları görülmektedir (Çizelge 9). 


\section{A.Altanlar ve G.Akıncı Kesim}

Çizelge 9. Yöre halkı ve yerli turistlerin memnuniyetlerini azaltan etmenlerin yaş dağılımı ile karşılaştırılması.

\begin{tabular}{|c|c|c|c|c|c|c|}
\hline Faktörler & Yaş Dağılımı & $\mathrm{N}$ & $\begin{array}{l}\text { A.O. } \\
\bar{X}\end{array}$ & s.s. & $\mathrm{F}$ & $\mathrm{P}$ \\
\hline \multirow{6}{*}{$\begin{array}{l}\text { Donatı, Konaklama ve } \\
\text { Tanıtım Eksikliği }\end{array}$} & 19 ve alt 1 & 37 & 3,0855 & 0,94690 & \multirow{6}{*}{4,582} & \multirow{6}{*}{$* * * 0,000$} \\
\hline & $20-29$ & 215 & 3,5777 & 0,99051 & & \\
\hline & $30-39$ & 78 & 3,5852 & 0,93005 & & \\
\hline & $40-49$ & 48 & 3,1146 & 0,93276 & & \\
\hline & $50-59$ & 31 & 3,0173 & 0,95421 & & \\
\hline & 60 ve üzeri & 11 & 3,2500 & 0,94818 & & \\
\hline \multirow{6}{*}{$\begin{array}{l}\text { Alt Yapı, Bakım ve } \\
\text { Onarım Eksikliği }\end{array}$} & 19 ve alt1 & 37 & 3,5568 & 0,91547 & \multirow{6}{*}{2,246} & \multirow{6}{*}{$* 0,049$} \\
\hline & $20-29$ & 214 & 4,0357 & 0,89085 & & \\
\hline & $30-39$ & 78 & 4,0844 & 0,92058 & & \\
\hline & $40-49$ & 48 & 3,9021 & 0,86719 & & \\
\hline & $50-59$ & 30 & 3,8867 & 0,80290 & & \\
\hline & 60 ve üzeri & 11 & 3,7818 & 1,21393 & & \\
\hline \multirow{6}{*}{$\begin{array}{l}\text { Taşıma Kapasitesinin } \\
\text { Aş1lması }\end{array}$} & 19 ve alt 1 & 37 & 2,3243 & 1,15600 & \multirow{6}{*}{1,038} & \multirow{6}{*}{0,395} \\
\hline & $20-29$ & 214 & 2,3528 & 1,10943 & & \\
\hline & $30-39$ & 77 & 2,4892 & 1,04655 & & \\
\hline & $40-49$ & 47 & 2,5390 & 1,14747 & & \\
\hline & $50-59$ & 30 & 2,2556 & 1,11308 & & \\
\hline & 60 ve üzeri & 11 & 1,8182 & 0,89893 & & \\
\hline \multirow{5}{*}{$\begin{array}{l}\text { Gürültü ve Görüntü } \\
\text { Kirliliği }\end{array}$} & 19 ve alt 1 & 37 & 2,6036 & 0,93797 & \multirow{5}{*}{3,188} & \multirow{5}{*}{$* * 0,008$} \\
\hline & $20-29$ & 214 & 2,7882 & 1,06549 & & \\
\hline & $30-39$ & 78 & 3,2318 & 0,99064 & & \\
\hline & $40-49$ & 47 & 3,0904 & 0,97506 & & \\
\hline & $50-59$ & 29 & 3,0144 & 0,92020 & & \\
\hline
\end{tabular}

Katılımcıların bu dört faktör gruplarına ilişkin yanıtları incelendiğinde; "donatı, konaklama ve tanıtım eksikliğgi", "altyapı, bakım ve onarım eksikliği” faktörleri ile gelir dağılımı arasında anlamlı bir farklılık bulunmadığı, "taşıma kapasitesinin aşılması", "gürültü ve görüntü kirliliği”, faktörleri ile gelir dağılımları arasında ise anlamlı bir farklılık bulunduğu tespit edilmiştir. Taşıma kapasitesinin aşılması 500 TL'den az gelire sahip yöre halkı ve yerli turistlerin memnuniyet düzeyini en fazla olumsuz etkilerken, 500-1000 TL arası gelir düzeyine sahip olan yöre halk1 ve yerli turistlerin memnuniyet düzeylerinin diğer gelir gruplarına göre nispeten daha az olumsuz etkilendiği görülmektedir. "Gürültü ve görüntü kirliliğgi" faktörlerine verilen yanıtlara ilişkin ortalamalar incelendiğinde ise; 1001-1500 TL gelir düzeyine sahip olan katılımcıların memnuniyet düzeyinin diğer gelir düzeylerine göre çok olumsuz bir eğilim içinde olduğu tespit edilmiştir (Çizelge 10). 

Araştırma; Akçakoca Örneği

Çizelge 10. Yöre halkı ve yerli turistlerin memnuniyetlerini azaltan etmenlerin gelir dağılımı ile karşıllaştırılması.

\begin{tabular}{|c|c|c|c|c|c|c|}
\hline Faktörler & Gelir Dağılımı & $\mathrm{N}$ & $\begin{array}{c}\text { A.O. } \\
\bar{X}\end{array}$ & s.s. & $\mathrm{F}$ & $\mathrm{P}$ \\
\hline \multirow{5}{*}{$\begin{array}{l}\text { Donatı, Konaklama } \\
\text { ve Tanıtım Eksikliği }\end{array}$} & 500den az & 114 & 3,4348 & 1,02961 & \multirow{5}{*}{0,065} & \multirow{5}{*}{0,992} \\
\hline & $500-1000$ & 134 & 3,4339 & 0,97292 & & \\
\hline & $1001-1500$ & 67 & 3,4980 & 0,98500 & & \\
\hline & $1501-2000$ & 32 & 3,4124 & 1,02351 & & \\
\hline & 2001 ve üstü & 32 & 3,4263 & 1,01477 & & \\
\hline \multirow{5}{*}{$\begin{array}{l}\text { Alt Yapı, Bakım ve } \\
\text { Onarım Eksikliği }\end{array}$} & 500den az & 114 & 3,9522 & 0,89526 & \multirow{5}{*}{0,302} & \multirow{5}{*}{0,876} \\
\hline & $500-1000$ & 133 & 4,0113 & 0,89285 & & \\
\hline & $1001-1500$ & 67 & 3,9251 & 0,97642 & & \\
\hline & $1501-2000$ & 32 & 4,0750 & 0,92806 & & \\
\hline & 2001 ve üstü & 31 & 4,0806 & 0,80433 & & \\
\hline \multirow{5}{*}{$\begin{array}{l}\text { Taşıma Kapasitesinin } \\
\text { Aş1lması }\end{array}$} & 500den az & 114 & 2,6053 & 1,15454 & \multirow{5}{*}{3,611} & \multirow{5}{*}{$* 0,007$} \\
\hline & $500-1000$ & 132 & 2,1263 & 0,99939 & & \\
\hline & $1001-1500$ & 66 & 2,5783 & 1,10137 & & \\
\hline & $1501-2000$ & 32 & 2,4062 & 1,13824 & & \\
\hline & 2001 ve üstü & 32 & 2,3229 & 1,06251 & & \\
\hline \multirow{5}{*}{$\begin{array}{l}\text { Gürültü ve Görüntü } \\
\text { Kirliliği }\end{array}$} & 500den az & 114 & 2,8041 & 1,01658 & \multirow{5}{*}{2,641} & \multirow{5}{*}{$* 0,034$} \\
\hline & $500-1000$ & 132 & 2,8819 & 1,05515 & & \\
\hline & $1001-1500$ & 67 & 3,2836 & 1,06235 & & \\
\hline & $1501-2000$ & 32 & 2,7734 & 0,94476 & & \\
\hline & 2001 ve üstü & 31 & 2,8763 & 1,04768 & & \\
\hline
\end{tabular}

${ }^{*} \mathrm{p}<0,05,{ }^{* *} \mathrm{p}<0,005, * * * \mathrm{p}<0,001$, A.O: Aritmetik Ortalama

Akçakoca'daki yöre halk1 ile yerli turistlerin memnuniyetlerini azaltan faktörler arasında anlamlı bir farklılık bulunup bulunmadığına ilişkin yapılan $\mathrm{T}$ testinin sonuçlarına göre, "donatı, konaklama ve tanıtım eksikliği”, "taşıma kapasitesinin aşılması", "gürültü ve görüntü kirliliği” olarak gruplandırılan faktörlerin yöre halkının memnuniyetlerine dair görüşlerini yerli turistlere göre daha olumsuz etkilerken, "altyapı bakım ve onarım eksikliği”" faktörüne ilişkin belirttikleri görüşler üzerinde herhangi bir etkisinin olmadığı görülmektedir (Çizelge 11).

Çizelge 11. Yöre halkı ve yerli turistlerin memnuniyetlerini azaltan etmenlerin ikametgah ile karşılaştırılması.

\begin{tabular}{|c|c|c|c|c|c|c|c|}
\hline Faktörler & İkametgah durumu & $\mathrm{N}$ & $\begin{array}{l}\text { A.O. } \\
\bar{X}\end{array}$ & s.s & s.d & $\mathrm{t}$ & $\mathrm{p}$ \\
\hline \multirow{2}{*}{$\begin{array}{l}\text { Donatı, Konaklama ve } \\
\text { Tanıtım Eksikliği }\end{array}$} & $\begin{array}{l}\text { Akçakoca' da } \\
\text { yaşıorum }\end{array}$ & 186 & 3,5638 & 1,00679 & \multirow{2}{*}{417} & \multirow{2}{*}{2,376} & \multirow{2}{*}{$* 0,018$} \\
\hline & $\begin{array}{l}\text { Akçakoca' da } \\
\text { yaşamıyorum }\end{array}$ & 233 & 3,3351 & 0,95589 & & & \\
\hline \multirow{2}{*}{$\begin{array}{l}\text { Alt Yapı, Bakım ve } \\
\text { Onarım Eksikliği }\end{array}$} & $\begin{array}{l}\text { Akçakoca' da } \\
\text { yaşıorum }\end{array}$ & 185 & 4,0661 & 0,86198 & \multirow{2}{*}{415} & \multirow{2}{*}{1,892} & \multirow{2}{*}{0,059} \\
\hline & $\begin{array}{l}\text { Akçakoca' da } \\
\text { yaşamıyorum }\end{array}$ & 232 & 3,8978 & 0,93356 & & & \\
\hline \multirow{2}{*}{$\begin{array}{l}\text { Taşıma Kapasitesinin } \\
\text { Aşılması }\end{array}$} & $\begin{array}{l}\text { Akçakoca' da } \\
\text { yaşıyorum }\end{array}$ & 185 & 2,5162 & 1,15889 & \multirow{2}{*}{413} & \multirow{2}{*}{2,399} & \multirow{2}{*}{$* 0,017$} \\
\hline & $\begin{array}{l}\text { Akçakoca' da } \\
\text { yaşamıyorum }\end{array}$ & 230 & 2,2572 & 1,03675 & & & \\
\hline \multirow{2}{*}{$\begin{array}{l}\text { Gürültü ve Görüntü } \\
\text { Kirliliği }\end{array}$} & $\begin{array}{l}\text { Akçakoca' da } \\
\text { yaş1yorum }\end{array}$ & 185 & 3,1117 & 1,02279 & \multirow{2}{*}{413} & \multirow{2}{*}{3,557} & \multirow{2}{*}{$* * * 0,000$} \\
\hline & $\begin{array}{l}\text { Akçakoca' da } \\
\text { yaşamıyorum }\end{array}$ & 230 & 2,7536 & 1,01662 & & & \\
\hline
\end{tabular}

${ }^{*} \mathrm{p}<0,05,{ }^{* *} \mathrm{p}<0,005, * * * \mathrm{p}<0,001$, A.O: Aritmetik Ortalama 


\section{A.Altanlar ve G.Akıncı Kesim}

3.6. Yerli Turistlerin Seyahat Özellikleri ile Memnuniyetlerini Belirleyen Etmenlerin Karşılaştırılması

- Yerli Turistlerin Seyahat Özellikleri ile Memnuniyetlerini Arttıran Etmenlerin Karşılaştırılması

Yerli turistlerin seyahat özellikleri (ziyaret sayısı, geliş sıklığı, konaklama süresi) ile Akçakoca'daki turizm alanları ve faaliyetleri açısından memnuniyetlerini belirleyen etmenler arasında anlamlı bir farklılık bulunup bulunmadığına ilişkin, Bağımsız Örneklemler İçin Tek-Faktörlü Varyans Analizi (One-Way ANOVA) yapılmıştır. Yapılan varyans analizi sonucunda elde edilen istatistiki verilere göre, yerli turistlerin yöreye geliş sıklıkları, ziyaret sayısı ve konaklama sürelerinin her üç faktör ile ilgili görüşlerini etkilemediği belirlenmektedir (Altanlar, 2007).

Yerli turistlerin, konaklama süresi ile gruplandırılan bu üç faktördeki yargılara ilişkin sundukları görüşleri karşılaştırıldığında ise; yörede konaklama süresinin, "doğal alanlardan aktif olarak faydalanma isteği" faktörü ile anlamlı bir farklılık göstermezken, "doğal alanlardan pasif olarak faydalanma isteği" ve "sosyal aktivite odaklı fayda sağlama isteği" faktörleri ile anlamlı bir farklılık gösterdiği belirlenmektedir. Sonuç olarak, yerli turistlerin konaklama süresi arttıkça "doğal alanlardan faydalanma isteği" ve "sosyal odaklı faydalanma isteği" faktörlerine dair memnuniyetlerinin nispeten daha az olumlu olduğu tespit edilmiştir (Çizelge 12).

Çizelge 12. Yerli turistlerin memnuniyetlerini arttıran etmenlerin konaklama süresi ile karşılaştırılması.

\begin{tabular}{|c|c|c|c|c|c|c|}
\hline Faktörler & Konaklama süresi & $\mathrm{N}$ & $\begin{array}{l}\text { A.O. } \\
\bar{X}\end{array}$ & S.S. & $\mathrm{F}$ & $\mathrm{P}$ \\
\hline \multirow{6}{*}{$\begin{array}{l}\text { Doğal Alanlardan Aktif Olarak } \\
\text { Faydalanma İsteği }\end{array}$} & Günübirlik & 69 & 2,4689 & 0,74488 & \multirow{6}{*}{1,135} & \multirow{6}{*}{0,343} \\
\hline & 1-3gün & 38 & 2,2950 & 0,78824 & & \\
\hline & 4-6 gün & 11 & 2,3030 & 0,54227 & & \\
\hline & Bir hafta & 21 & 2,5026 & 0,96586 & & \\
\hline & 15 gün & 17 & 2,0993 & 0,98548 & & \\
\hline & Bir ay ve fazla & 65 & 2,2342 & 0,73749 & & \\
\hline \multirow{6}{*}{$\begin{array}{l}\text { Doğal Alanlardan Pasif Olarak } \\
\text { Faydalanma İsteği }\end{array}$} & Günübirlik & 71 & 3,2797 & 0,68753 & \multirow{6}{*}{3,145} & \multirow{6}{*}{$* 0,009$} \\
\hline & 1-3gün & 41 & 3,4817 & 0,66579 & & \\
\hline & 4-6 gün & 11 & 3,7354 & 0,68180 & & \\
\hline & Bir hafta & 21 & 3,5238 & 0,65146 & & \\
\hline & 15 gün & 17 & 2,9086 & 0,58698 & & \\
\hline & Bir ay ve fazla & 65 & 3,2188 & 0,74392 & & \\
\hline \multirow{6}{*}{$\begin{array}{l}\text { Sosyal Aktivite Odaklı Fayda } \\
\text { Sağlama İsteği }\end{array}$} & Günübirlik & 69 & 2,4783 & 1,16769 & \multirow{6}{*}{3,404} & \multirow{6}{*}{$* 0,006$} \\
\hline & 1-3gün & 39 & 2,6667 & 0,90564 & & \\
\hline & 4-6 gün & 11 & 3,7273 & 1,21169 & & \\
\hline & Bir hafta & 20 & 3,0500 & 1,08700 & & \\
\hline & 15 gün & 16 & 2,3125 & 1,26326 & & \\
\hline & Bir ay ve fazla & 64 & 2,5234 & 1,08901 & & \\
\hline
\end{tabular}

${ }^{*} \mathrm{p}<0,05,{ }^{* *} \mathrm{p}<0,005,{ }^{* * *} \mathrm{p}<0,001$, A.O: Aritmetik Ortalama

- Yerli Turistlerin Seyahat Özellikleri ile Memnuniyetlerini Azaltan Etmenlerin Karşılaştırılması

Ankete katılan turistlerin ziyaret sayısı, geliş sıklı̆̆ ve konaklama süresi ile "donatı ve konaklama eksikliği”, "alt yapı bakım ve onarım eksikliği”, "taşıma kapasitesinin aşılması" ve "gürültü ve görüntü kirliliği”" faktörlerine ilişkin cevaplar arasındaki ilişkiyi incelemek amacıyla yapılan Bağımsız Örneklemler için Tek-Faktörlü Varyans Analizi (One-Way ANOVA)'nin sonuçlarına göre anlamlı bir farklılık olduğu tespit edilen faktörler Çizelge 13’te verilmiştir. 
Ankete katılan turistlerin, ziyaret sayısı ile "donatı ve konaklama eksikliği”, "alt yapı bakım ve onarım eksikliğị", "taşıma kapasitesinin aşılması" ve "gürültü ve görüntü kirliliği" faktörlerine ilişkin cevaplar arasındaki ilişki incelendiğinde; yöreyi ilk kez ziyaret eden turistlerin donatı, konaklama ve tanıtım eksikliğini memnuniyetleri açısından çok fazla sorun olarak belirtirken, ikinci kez gelenlerin nispeten daha az sorun olarak belirttiği görülmektedir (Çizelge 13).

Ankete katılan yerli turistlerin, geliş sıklığı ile söz konusu dört faktör arasındaki ilişki incelediğinde ise; sadece "taşıma kapasitesinin aşılması" faktörü ile geliş sıklı̆̆ 1 arasında anlamlı bir farklılık bulunduğu tespit edilmiştir. Bu faktöre verdikleri yanıtlara ilişkin ortalamalara bakıldığında; diğer (yaz sezonunda sürekli ya da 5-6 kez, tatillerde ve okul dönemi boyunca hafta içi) seçeneğini işaretleyerek görüş bildiren turistlerin taşıma kapasitesinin aşılması olarak gruplandırılan yargılara ilişkin görüşlerinin daha olumsuz olduğu görülmektedir (Çizelge 13).

Ankete katılan yerli turistlerin konaklama süresi ile faktörlere ilişkin verdiği yanıtlar incelendiğinde; "alt yapı bakım ve onarım eksikliği" faktörü ile "konaklama süresi" arasında anlamlı bir farklılık bulunduğu tespit edilmiştir. Çizelge 13'teki veriler incelendiğinde; yerli turistlerin, "donatı, konaklama ve tanıtım eksikliği", "taşıma kapasitesinin aşılması" ve "gürültü ve görüntü kirliliği" faktörlerine verdikleri yanıtlara ilişkin ortalamaların birbirlerine yakın değerler içerdiği görülebilmektedir. Yerli turistlerin "alt yapı, bakım ve onarım eksikliği”" faktör grubuna verdikleri yanıtlara ilişkin ortalamalara bakıldığında ise; konaklama süresi uzadıkça Akçakoca'da konaklayan turistlerin, "alt yapı bakım ve onarım eksikliği" faktöründe yer alan yargılara ilişkin memnuniyetlerinin daha olumsuz etkilendiği ve alt yapı bakım ve onarım eksikliklerini sorun olarak gördükleri tespit edilmiştir.

Çizelge13. Yerli turistlerin memnuniyetlerini azaltan etmenlerin ziyaret sayısı, geliş sıklığı ve konaklama süresi ile karşılaştırılması.

\begin{tabular}{|c|c|c|c|c|c|c|}
\hline \multicolumn{7}{|c|}{, } \\
\hline Faktörler & Ziyaret sayıs1 & $\mathrm{N}$ & $\begin{array}{l}\text { A.O. } \\
\bar{X}\end{array}$ & s.s. & $\mathrm{F}$ & $\mathrm{P}$ \\
\hline \multirow{4}{*}{$\begin{array}{l}\text { Donatı, Konaklama ve Tanıtım } \\
\text { Eksikliği }\end{array}$} & Ilk kez & 18 & 3,9276 & 0,97476 & \multirow{4}{*}{3,047} & \multirow{4}{*}{$* 0,030$} \\
\hline & Ikinci kez & 8 & 3,2031 & 1,11391 & & \\
\hline & Üçüncü kez & 8 & 3,2701 & 1,25522 & & \\
\hline & Dört ve fazla & 185 & 3,2403 & 0,89748 & & \\
\hline Faktör & Geliş sıklığ1 & $\mathrm{N}$ & $\begin{array}{l}\text { A.O. } \\
\bar{X}\end{array}$ & s.s. & $\mathrm{F}$ & $\mathrm{P}$ \\
\hline \multirow{7}{*}{ Taşıma Kapasitesinin Aşılması } & Haftada bir & 17 & 2,0588 & 0,80997 & \multirow{7}{*}{2,163} & \multirow{7}{*}{$* 0,048$} \\
\hline & 15 günde bir & 27 & 1,9877 & 0,65686 & & \\
\hline & Ayda bir & 22 & 1,9091 & 0,92113 & & \\
\hline & Üç ayda bir & 32 & 2,5313 & 1,21183 & & \\
\hline & Alt1 ayda bir & 24 & 2,2153 & 1,09067 & & \\
\hline & Y1lda bir & 51 & 2,1895 & 0,96438 & & \\
\hline & Diğer & 45 & 2,6000 & 1,13396 & & \\
\hline Faktör & $\begin{array}{l}\text { Konaklama } \\
\text { Süresi }\end{array}$ & $\mathrm{N}$ & $\begin{array}{l}\text { A.O. } \\
\bar{X}\end{array}$ & s.s. & $\mathrm{F}$ & $\mathrm{P}$ \\
\hline \multirow{6}{*}{$\begin{array}{l}\text { Alt Yap1, Bakım ve Onarım } \\
\text { Eksikliği }\end{array}$} & Günübirlik & 69 & 3,6935 & ,98069 & \multirow{6}{*}{2,616} & \multirow{6}{*}{$* 0,025$} \\
\hline & 1-3gün & 39 & 3,5692 & 1,00267 & & \\
\hline & 4-6 gün & 11 & 4,0364 & 1,09112 & & \\
\hline & Bir hafta & 21 & 4,0857 & 0,84041 & & \\
\hline & 15 gün & 17 & 4,0618 & 0,94199 & & \\
\hline & Bir ay ve fazla & 65 & 4,1015 & 0,77952 & & \\
\hline
\end{tabular}

\section{Tartışma ve Sonuç}

Akçakoca, hem bir kıyı kenti, hem de doğal güzellikleri ile 1947 yılında daha Ege ve Akdeniz kıyıları henüz turizme açılmamışken, turizm potansiyeli keşfedilmiş bir ilçe olması ile turizm 


\section{A.Altanlar ve G.Akıncı Kesim}

açısından önemli bir konumdadır. Öyle ki daha Türkiye'de turizm ile ilgili bir Bakanlık kurulmadan önce, Akçakoca'da "Akçakoca Turizm Derneğii" adıyla bir dernek kurulmuş ve Akçakoca, 19501970'li yıllar arasında gelişen iç ve dış turizme hizmet vermiştir. Fakat daha sonraki yıllar sahipsizlik ve ilgisizlik ilçede turizmi geriletmiş, hatta duraklama noktasına getirmiştir. 1990'lı yıllardan itibaren yerel yönetimlerin öncülügünde Akçakoca'da turizm sektörü yeniden ilerleme kaydetmeye başlamıştır. Günümüzde Akçakoca, varolan turizm potansiyeli nedeniyle Kültür ve Turizm Bakanlığı 2023 Türkiye Turizm Stratejisi içerisinde Batı Karadeniz kıyı koridorunun iç turizm gelişim koridoru olarak geliştirilmesi stratejisi kapsamında kültür, kıyı ve doğa turizmi çerçevesinde geliştirilmesi gereken 500 km'lik bölge içerisinde yer almaktadır (Altanlar, 2007). Sonuç olarak, geçmişten günümüze tutarlı bir turizm politikası geliştirilemediği için turizmde hak ettiği yeri alamayan Akçakoca'da, değişen turizm anlayışına uyum sağlanması, turizmin dört mevsime yayılabilmesi ve sürdürülebilir bir turizm gerçekleştirilebilmesi için alternatif turizm olanaklarının ortaya konulması ve sürdürülebilir turizm stratejileri belirlenerek planlanması gerekliliği açıkça görülebilmektedir. Bölgede, turizm aktif halde olsa da plansız gelişmektedir. Turizmde kaliteyi arttırmak ve turistlerin davranış ve beklentilerini tespit etmek amacıyla müşteri memnuniyetine yönelik araştırmalar yapılmaktadır. Bu araştırmalar, daha çok temizlik, yer, fiyat, güvenlik, hizmet kalitesi, turizmle ilgili hizmet personelinin sahip olduğu hizmet bilgisi ve yardımseverliği, fiziksel çekicilikler, kalite ve ulaşılabilirlik konuları üzerinde yoğunlaşmaktadır (LeBlance, 1992). Turizm sektörünün doğal ve kültürel çekiciliklerinin değerlendirildiği düşünülürse, günümüz koşullarında müşteri memnuniyeti kadar, doğal alanların korunması üzerinde de ciddiyetle düşünülmesi gerekmektedir. Bu ihtiyaçtan doğan bir sonuç olarak, doğal alanlardaki koruma ve kullanma dengesini sağlamak için de müşteri memnuniyetine yönelik yöntemlerden yarar sağlanmaktadır (Burns ve ark., 1997). Bu araştırmada, yöre halkı ve yerli turistlerin turizm alanlarındaki memnuniyetlerini sosyo-ekonomik yapılarını ve turizm amaçlı faaliyetlerdeki genel eğilimlerini, alışkanlıklarını, turistlerin seyahat özelliklerini belirleyebilmek ve turizmde yanlış kaynak kullanımı ve plansız gelişmeden doğan çeşitli sorunları yerinde tespit etmek amacıyla anket çalışmasından yararlanılmıştır.

Roovers ve ark. (2002)' na göre rekreasyon aktivitelerinin açıklanması için kullanıcıların özellikleri çok önemli bir değişkendir. Sosyal sınıf, davranış ve tutumlardaki kültürel farklılıklar da müşteri beklenti ve algılamalarını etkileyebilmektedir (Kozak ve Rimmington, 2000). Araştırma alanında da sosyal sınıf ve kültürel farklılıkların beklentileri farklı etkilediği görülmüştür. Akçakoca' da ikamet eden yöre halkının "taşıma kapasitesinin aşılması", "gürültü ve görüntü kirliliği ile donatı", "konaklama ve tanıtım eksikliğini" turistlere göre daha fazla sorun olarak gördükleri tespit edilirken, yine yöre halkının "doğal alanlardan pasif olarak faydalanma isteği" ve "sosyal aktivite odaklı faydalanma isteği” olarak sınıflandırılan faktör gruplarındaki yargıların, memnuniyetlerini turistlere göre daha az olumlu etkilediği görülmektedir (Çizelge 8, Çizelge 11).

Burns ve ark. (1998)'nın yaptıkları çalışma, ziyaretçilerin yaşadıkları değişimin, alanın kalitesini belirleyen alt yapı ve hizmet beklentilerinde de etkili olduğunu belirtmektedir. Akçakoca'daki turizm alanlarında da kullanıcıların en çok altyapı ve hizmet konularındaki beklentilerinin karşılanamadığı görülmektedir. Turizm alanlarında daha çok yönetim, alt yapı eksikliği, taşıma kapasitesinin aşılması, donatı, konaklama ve tanıtım eksikliği gibi etmenlerin memnuniyeti olumsuz etkilediği görülmektedir ( Çizelge 9, Çizelge10). Araştırma alanında, yörenin ihtiyaç ve sorunlarını tespit edebilmek için stratejik bir planlama çalışması yapılması gerekmektedir. Ancak bu şekilde doğal ve kültürel kaynakları ile turizm olanaklarını tanıtan çalışmaların yapılması ve bunların tur ve organizasyonlarla desteklenmesi sağlanacak ve araştırma alanını daha seçici turistlerin ziyaret etmesi ve turistlerin beklentilerinin karşılanarak daha memnun ayrılmaları söz konusu olacaktır.

Gürbüz (2003)'ün, yerli turistlerin sosyo-ekonomik ve demografik özelliklerinin, tatmin düzeyi ve şikâyetleri üzerinde etkili olup olmadığına yönelik Safranbolu yöresinde gerçekleştirdiği araştırma, 
turistlerin bazı özellikleri ile memnuniyet düzeyleri arasında anlamlı ilişkilerin olduğunu ortaya koymuştur. $\mathrm{Bu}$ çalışmada da, yöre halkı ve yerli turistlerin sosyo-ekonomik ve demografik özelliklerinin bazıları ile turizm alanlardaki memnuniyetlerinin anlamlı bir farklılık gösterdiği tespit edilmiştir.

Bowes ve Dawson (1998)'nın yaptıkları çalışmada, alana geliş sıklığının kullanıcıların alandaki sorunlara ve kalabalığa olan toleranslarını azalttığını belirtmişlerdir. Bu araştırmada da, alana geliş sıklığı azaldıkça donatı, konaklama ve tanıtım eksikliği ve taşıma kapasitesinin aşılmasına karşı olan toleranslarının azaldığı ve beklentilerinin karşılanamadığı görülmektedir (Çizelge 13).

Kılıç (2002)'ın yaptığı çalışmada, Akçakoca'da çevreye ilişkin yapılan faaliyetlerden; yol yapım ve onarım çalışmalarına gereken önemi verme, park, bahçe ve yeşil alan konusunda sorumluluğunu yerine getirme, liman, sahil, cadde ve kaldırım gibi yerlerin çevre düzenlemesini yapma ve kanalizasyon, atık su ve çöp konularında gerekli hassasiyeti gösterip, denizi kirlilikten koruma konularında gerek yöre halkı, gerekse turizm işletmesi yöneticilerinin çok büyük bir çoğunluğu olumlu görüş bildirerek, belediye çalışmalarını başarılı bulduklarını belirtmişlerdir. Ancak bu çalışmada, yöre halkı ve yerli turistlerin bu faaliyetleri yetersiz olarak nitelendirdikleri ve sorun olarak görüş bildirdikleri ortaya konulmuştur.

Anket sonuçlarına göre turizm alanlarında tespit edilen genel sorunlar; Plansız yapılaşma, altyap1 ve üst yapı eksikliği (Arıtma ve İçme suyu yetersizliği), Rekreasyon amaçlı açık ve yeşil alanların yetersiz kalması, varolanların da bakım ve onarım çalışmalarının yetersizliği, Kamuya açık alanlarda donatı ve uyarı levhaları eksikliği, Çöp ve katı atıkların düzensiz depolanması, Konaklama tesislerinin eksik ve yetersiz olması, Tanıtım ve reklam eksikliği, Tur ve organizasyon eksikliği olarak özetlenebilmektedir. Bunlara ek olarak, yöre halkı ve yerli turistlerin doğa tabanlı turizm aktiviteleri ile kültürel yapıyı tanımaya yönelik deniz-güneş-kum üçlüsüne alternatif olacak turizm türlerine eğilim gösterdikleri, fakat Akçakoca'daki turizm faaliyetlerinin beklentilerinin çok daha altında kaldığı açıkça görülmektedir. Katılımcıların, Akçakoca'da yer alan alternatif turizm için uygun olabilecek alanları yoğunlukla tercih ettikleri görülmektedir. Yine turizm için potansiyel arz eden bu alanlara gitmelerini kısıtlayıcı nedenlerin genel olarak yönetim ve alt yapıdan kaynaklanan eksiklikler olduğu da belirlenmiştir.

Sonuç olarak; idari ve yerel yönetimler ile sivil toplum kuruluşlarının yanlış politikalar izlemesi ya da yetersiz kalması sonucu, yöre halkı ve yerli turistlerin beklentilerinin özellikle turizm faaliyetleri açısından tam olarak karşılanamadığı açıkça belirlenebilmektedir. Doğal ve kültürel kaynakların zenginliği dolayısıyla turist potansiyeline sahip olan ilçe, sezonluk planlamalarla alınan yanlış kararlar sonucunda turizm potansiyelini olumsuz etkileyen bir sürecin içine girmiştir. Özellikle çarpık kentleşmenin kaynakların kirlenmesine neden olduğu ve koruma - kullanma dengesi sağlanmadan yapılan her türlü faaliyetin Akçakoca ilçesinin turizm potansiyeline zarar verdiği görülmektedir. Bir kente turizm açısından geleceğe yönelik gerçekçi ve uygulanabilir politikalar ve planlar yapabilmek için öncelikle o kentin koşullarını belirleyen dinamikleri doğru olarak anlamak gerekmektedir. $\mathrm{Bu}$ amaçla kent, fiziksel ve beşeri altyapısından, kültür ve sanat alanlarını belirleyen ekonomik ve sosyal dinamiklere kadar geniş bir çerçevede incelenip objektif bir şekilde değerlendirilmelidir. $\mathrm{Bu}$ değerlendirmeyi doğru bir şekilde yapabilmek için kentteki doğal yapı, fiziksel altyapı, kültür sanat mekanları ve kültürel etkinliklerin belirlenmesi kadar kentlilerin değerlerini, yaşam alışkanlıklarını ve kentteki eğilimlerini de belirlemek gerekmektedir. Akçakoca gibi uzun yıllardır turizm amaçlı kullanılan ve turizm potansiyeli yüksek olan tüm yörelerin doğal ve kültürel kaynaklarının, sürdürülebilirliğini sağlamak amacıyla stratejik planlarının yapılması ve bu kapsamda alternatif doğal, tarihi ve kültürel kaynakların sürdürülebilmesi için alternatif turizm modellerinin geliştirilmesi gerekmektedir. 


\section{A.Altanlar ve G.Akıncı Kesim}

\section{Kaynaklar}

Altanlar, A. 2007. Akçakoca Alternatif Turizm Olanaklarının Araştırılması. AİBÜ Fen Bilimleri Enstitüsü, Peyzaj Mimarlığ1 Anabilim Dalı Basılmamış Yüksek Lisans Tezi, Düzce.

Bowes, S., Dawson, C.P. 1998. Watercraft User Motivations, Perceptions of Problems, and Preferences fof Management Action: Comparisons Between Three Levels of Past Experience. . Proceeding of The 1998 Northeastern Recreation Research Symposium. Northeastern Forest Experiment Station, GTR/NE-255. 149-155.

Burns, R.C., Graefe,A. R., Titre J. P. 1997. Costomer Satisfaction at Us Army Corps of Engineers- Administered Lakes: A Compilation of Two Years of Perfonmance Data. Proceedings of The 1997 Northeastern Recreation Research Symposium. USDA Forest Service. GTR. NE-241, 12-13.

Dawson, C.P., Newman, P., Watson, A. 1997. Cognitive Dimensions of Recreational User Experiences in Wilderness: An Exploratory Study in Adirondack Wilderness Areas. Proceedings of The 1997 Northeastern Recreation Research Symposium, 257-259, New York.

Enlil, Z., Dinçer, İ., Evren, Y., Seçkin, E. 2011. İstanbul'da Kültür Turizmi İçin Yenilikçi Stratejiler, İstanbul Bilgi Üniversitesi Yayınları, 26-37, İstanbul.

Erdoğan, N. 2003. Kitle Turizmi, Alternatif Turizm ve Ekoturizm Sürdürülebilirlik Üzerine Bir Değerlendirme. Türkiye'nin Alternatif Turizm Potansiyeli ve Güncel Sorunları Konferansı.

http://cmyo.ankara.edu.tr/ iktisad/TURKONF/program.htm. 10.10.2006.

Grodach, C., Loukaitou-Sideris, A. 2007. Cultural Development Strategies and Urban Revitalızatıon. International Journal of Cultural Policy, 13(4):349-370.

Gürbüz, A. 2003. Safranbolu'ya Gelen Yerli Turistlerin Tatmin Olma Düzeyini Belirlemeye Yönelik Bir Araştırma. Gazi Üniversitesi Ticaret ve Turizm Eğitim Fakültesi Dergisi, 6 (1): 1-21.

Keating, M. ve Frantz M. 2004. Culture-led Strategies for Urban Regeneration: a Comparative Perspective on Bilbao. International Journal of Iberian Studies, 16(3): 187-194.

Kılıç İ., Temeloğlu, E. 2004. Yerli Turistlerin Memnuniyet Düzeyleri Üzerine Bir Araştırma. Anatolia: Turizm Araştırmaları Dergisi, 15(2):113-124.

Kılıç N. 2003. Ekoturizm Planlmasına İlişkin Araştırmalarda Kullanılan Bazı Yöntemler. Ankara Üniversitesi Fen Bilimleri Enstitüsü, Peyzaj Mimarlığı Anabilim Dalı Basılmamış Doktora Tezi, Ankara.

Leblanc, G., 1992. Factors Effecting Customer Evaluation of Service Quality of Travel Agencies: An Invastigation of Customer Perceptions. Journal of Travel Research, 30 (4): 10-16.

Mackay, K., Crampton J.,L. 1990. Measuring The Quality of Recreation Services. Journal of Park and Recreation Administration, 8(3), 47-56.

Maitland, R., 2007. Culture, City Users and The Creation of New Tourism Areas in Cities. Tourism, Culture and Regeneration, CABI, 25-34, London.

Newman, P., Dawson, C.P. 1998. The Human Dimensions of The Wilderness Experience in The High Peaks Wilderness Area. Proceedings of The 1998 Northeastern Recreation Research Symposium. New York. GTR-NE-255 pp:122-128.

Özer, S.,U. 2010. Şehir Turizmi ve Kültür: Yabancı Turistlerin Kültürel Bir Destinasyon Olarak İstanbul'u Değerlendirmesi Üzerine Bir Araştırma. Anadolu Üniversitesi Şehir Sosyal Bilimler Enstitüsü Turizm ve Otel İşletmeciliği Anabilim Dalı Basılmamış Doktora Tezi. Eskişehir.

Parasurman, A., Zeithami, V. A., Berry, L. 1988. Servqual: A Multiple- item Scale for Measuring Consumer Perceptions of Quality. Journal of Retailing, 64, 12-40.

Roovers, P., Hermy, M., Gulinck, H., 2002. Visitor Profile Perceptions and Expection in Forests From A Gradient of Increasing Urbanisation in Central Belgium. Landscape and Urban Planing. 59:129-145.

Sınmaz, S., Altanlar, A., Çakıroğlu, A., Enlil, Z. 2010. Kültürel Gelişme Stratejileri Kapsamında İstanbul'da Dönüşüm Potansiyeli Taşıyan Sanayi Alanlarının Yeniden Canlandırılmasına Yönelik Bir Yaklaşım. Uluslararası 21. Kentsel Tasarım ve Uygulamalar Sempozyumu (13-14 Ekim 2010), Bildiri Kitabı (Basımda). İstanbul.

Kerimoğlu, E., Çıracı, H. 2006. “İstanbul'da Uluslararası Ziyaretçilerin Memnuniyet Düzeyleri”, İTÜ Dergisi /a, 5(1): 35-46.

Türkün, A., 2007. Kentsel Turizmin Gelişmiş ve Az Gelişmiş Ülkelerdeki Yansımaları. TMMOB İstanbul Kent Sempozyumu (13-15 Eylül 2007) Bildiriler Kitabı, 221, İstanbul..

Ural, A., Kılıç, İ. 2005. Bilimsel Araştırma Süreci ve SPSS ile Veri Analizi. Detay Yayınc1lık. 274. Ankara. 